Discussion Paper No. 04-72

\title{
Determinants of \\ Patent Litigation in Germany
}

Katrin Cremers

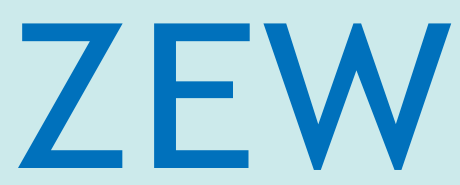

Zentrum für Europäische Wirtschaftsforschung $\mathrm{GmbH}$

Centre for European

Economic Research 
Discussion Paper No. 04-72

\title{
Determinants of Patent Litigation in Germany
}

\author{
Katrin Cremers
}

Download this ZEW Discussion Paper from our ftp server:

ftp://ftp.zew.de/pub/zew-docs/dp/dp0472.pdf

Die Discussion Papers dienen einer möglichst schnellen Verbreitung von neueren Forschungsarbeiten des ZEW. Die Beiträge liegen in alleiniger Verantwortung der Autoren und stellen nicht notwendigerweise die Meinung des ZEW dar.

Discussion Papers are intended to make results of ZEW research promptly available to other economists in order to encourage discussion and suggestions for revisions. The authors are solely responsible for the contents which do not necessarily represent the opinion of the ZEW. 


\section{Non-Technical Summary}

Patents are intellectual property rights to exclude others from using an innovation and to recoup the investment into R\&D. However, this right has no purpose if it is not enforced against infringement which is in turn a costly process with strategic elements. This paper analyzes the determinants of patent infringement suits in Germany.

At the beginning, a short introduction into the German patent system and the litigation system explains that the system is highly centralized because of the necessity of jurisdictionally and technically experienced judges. Two special features of the system make it especially interesting to analyze the determinants of patent litigation in Germany: First, there is a strict separation between enforcement after infringement of a valid patent on one hand and enforcement after attacking the validity of the patent directly by means of opposition or annulment on the other hand. This is different to the U.S. and most other patent systems of the world. A second more technical speciality is the parallel existence of two patent systems, the German and the European with only one enforcement system, the national district courts.

Analyzing the determinants patent litigation, I follow a selection model of Priest und Klein (1984) with symmetric information and diverging expectations about the winning probabilities. Litigation is assumed to be a failure of settlement in pre-trail negotiations. The model predicts that the differences in the expected values will lower the likelihood of settlement and raise the probability of litigation. The main hypotheses state that the parties will go to trial if their expected return net of legal costs will be equal or larger than the expected outcome of a settlement. These expected values depend mainly on the value of the patent, the characteristics of the patentees and the technological and economic conditions.

The empirical analysis employs a data set of 714 patent infringement suits encompassing 824 patents. The suits were filed at two of the three main district courts in Germany, Mannheim and Düsseldorf in 1993 to 1995. In order to analyze the determinants of patent litigation a control group has been created. For each litigated patent one unlitigated patent of the same year of application and the same 4-digit IPC-class has been selected from the universe of all German patents filed. A probit analysis tests how the sample probability of litigation for a single patent depends on the value of the patent and the characteristics of the patentees. Variables correlated with the value of the patent, such as the number of citations made and received, the size of the patent family, the number of claims, and the path of seeking patent protection within the German and European market were included. Control variables such as earlier opposition procedures and the path of seeking protection were included. The results strongly support the hypotheses that the expected patent value has a positive and significant impact on the probability of litigation. Patents which survived an opposition procedure have a higher probability of being litigated while the path of seeking protections has no significant effect. Individuals face a smaller probability of being involved in patent suits while small firms have the highest risk of litigation. Those firms have relatively high stakes involved and may show a self serving bias which leads to higher expected probabilities of winning the case than the potential defendant. 


\title{
Determinants of Patent Litigation in Germany
}

\author{
by \\ KATRIN CREMERS
}

Centre for European Economic Research (ZEW), Mannheim

12. Oktober 2004

\begin{abstract}
This paper presents an empirical analysis of the determinants of patent litigation in Germany, based on information from suits filed during the period from 1993 to 1995 at two of the three most important district courts. A control group was formed by selecting a random sample from the population data taken at this period of time. The results of a probit analysis show that relatively valuable patents are more likely to be involved in litigation cases than the average patent. Patents which have survived opposition are more likely to encounter subsequent litigation actions after the granting procedure than patents which have not been opposed. Patent owner's ability to trade patents with potential infringers and to interact with them repeatedly appears to promote pretrial settlement and to prevent patentees from filing suits. In contrast to results for the U.S., individual patent owners in Germany were found to be no more likely to face litigation than companies.
\end{abstract}

JEL classification: K41, O34

Keywords: Patent, Infringement, Litigation, Innovation

Acknowledgement: I am grateful to Dietmar Harhoff, Joachim Henkel, Georg Licht, Bettina Peters, Konrad Stahl, and participants of the Annual Conference of the Verein für Socialpolitik 2003 in Zurich, and the department seminar of Industrial Economics and International Management of the Centre for European Economic Research (ZEW) for valuable comments and discussion. Financial support by the German Science Foundation (DFG) under the grant SFB/TR 15 - 04 is gratefully acknowledged.

address: ZEW, Center for European Economic Research, Department of Industrial Economics and International Management P.O. Box 1034 43, D-68034 Mannheim, Germany

phone: +49-621-1235-297

fax: $\quad+49-621-1235-170$

e-mail: cremers@zew.de 


\section{Introduction}

The original function of intellectual property rights (IPR) was to provide an instrument to ensure inventors the ability to recoup the investment made in research. However, awareness of the importance of this original function has declined during the last 20 years. Other ways of appropriation such as secrecy and first mover advantage are often much more successful in exploiting innovation. ${ }^{1}$ Furthermore, inventions are increasingly produced on a mass scale to build up a knowledge stock, which is necessary in some technological areas to keep up with technological progress in cumulative technologies. ${ }^{2}$ As a result, the number of patent applications and grants has risen during these years. In rapidly changing areas of technology, patenting behavior has a signaling character showing the direction of new development. More strategic functions of patents are widely recognized, such as signaling market potential in assigned fields of technology, safeguarding former patents by enhancing inventions, or building a patent stock that can be used as a bargaining chip in negotiations on new technologies and mergers. Additionally, licensing and cross licensing have evolved into a large-scale profit source for innovative firms with capacity constraints or a need for complementary technology. Patents have become strategic weapons, and the enforcement of IPR has become a strategic means in technological competition.

This paper analyzes the characteristics of patent infringement suits in Germany. This is economically interesting because patent infringement suits are a costly way of enforcing intellectual property rights. Patenting itself is a costly process, and enforcing a granted property right against infringement is likewise associated with costs, namely time and expenditure of the legal process. In addition, the uncertainty during the dispute is linked with opportunity cost. In some cases opposition procedures, challenge or nullity suits are filed against granted patents. These procedures and suits are part of the enforcement. A potential litigation suit before a district court is the last and most costly alternative to enforce a patent right. In all of these disputes, there is always a possibility of settlement. That means a license or cross-license agreement could be found to the satisfaction of both parties. If patenting has a strategic character, then enforcement of patent rights includes strategic elements as well. Enforcement of IPR includes a successful application and granting procedure at the patent office. The most crucial argument in favor of the decision to file a suit is the expected value of the dispute. This value depends mainly on the value of the patented innovation but also on the characteristics of the parties and technological and economic conditions involved.

The estimated litigation rate in Germany is about 1 percent of all patents in force at any given time. This figure seems quite low. However, large differences between various fields of technology can be observed. It is expected that the probability of litigation will be higher for more valuable patents (Lanjouw und Schankerman 2003, Harhoff und Reitzig 2004). The distribution of the value of patents is highly skewed, meaning that most patents have little value. ${ }^{3}$ Accordingly, the number of litigation cases is low, compared to the total number of patents in force. However, the rate of litigation remained constant even with growing numbers of application and grants. ${ }^{4}$ The analysis of the German system is of special interest because, compared to the U.S. system it works with relatively low costs and it seems to be the fairest system from an offensive and defensive perspective (Blackburn 2000).

After an IPR infringement is detected, the patentee may decide to negotiate the issue with the infringer. Using a game theoretic approach it is clear that with symmetric and complete information the parties should always come to a settlement solution (Bebchuk (1984), Meurer (1989)). This result would minimize the cost of the dispute, maximize the profits from the invention and optimize the compensation for both parties with respect to welfare. If this is optimal, the question may arise why at least one patent or utility suit is nevertheless filed per day in Germany. One explanation for this failure of settlement in infringement disputes could be that the parties form different expectations about the payoffs and about their probability to prevail at trial, even though they have access to the same information.

\footnotetext{
${ }^{1}$ See Cohen et al. (2000) for survey evidence.

${ }^{2}$ See e.g. Hall und Ziedonis (2001).

${ }^{3}$ See Harhoff et al. (2003b) for an analysis of the patent value distribution at their high value end.

${ }^{4}$ I calculated this rate by comparing the numbers in Stauder (1989) with the data I collected for the district courts in Mannheim and Duesseldorf.
} 
This paper is the first empirical analysis of the determinants of patent and utility litigation in Germany. A new and unique data set of 715 IPR cases gives new insight into the course and outcome of litigation disputes. The data include all cases filed at two of the three main district courts in Germany during the period from 1993 to $1995 . .^{5}$ These patent and utility suits covered 910 IPRs in litigation. The data were combined with patent information from the German Patent Office (DPMA) and the European Patent Office (EPO), both located in Munich. Furthermore, a control group of 850 German patents randomly drawn from the population of all patents has ensured a comparable investigation and provided the possibility to develop a system of determinants of IPR litigation in Germany.

Within a probit estimation I analyze the probability of litigation as a function of a set of exogenous variables which reflect characteristics of the patent, market conditions, and characteristics of the patent owner. As expected, I observe a higher probability of litigation for patents which are more valuable than average. This is significant for all patent characteristics which were proved to be correlated with the value of the patent (Harhoff et al. 2003). Another telling result is the significantly higher probability of small firms being involved in a patent litigation suit, which points to the relatively high value patents have for the small companies compare to larger ones. This conclusion has a substantial impact on the conditions of insurance contracts against the risk of patent litigation.

This paper is organized as follows: In section 2 I outline the German litigation procedure. In section 3 I sketch a model of the decision to litigate and derive hypotheses about the determinants of patent litigation. Section 4 contains a description of the database and the control group formation process. Empirical results for Germany are presented in section 5. In conclusion, in section 6 I discuss the results obtained.

\section{The German System of Patent Litigation}

A patent can be subject to litigation before a German district court if it is valid in Germany. The original application may have been filed at the German Patent Office, as a Patent Cooperation Treaty (PCT) patent or at the European Patent Office, with Germany as the designated state in the latter cases. Before 1976 patent protection for Germany was only available at the DPMA. It received all applications; its examiners conducted search and examination. On average, $61 \%$ of the applications resulted in a German patent grant. ${ }^{6}$ The requirements for patentability of an invention are novelty, inventive activity, and commercial applicability ( $\S 1$, German Patent Act). "Novel" is that which is not state of the prior art. An invention is the result of inventive activity if the activity is not obvious to an expert on the state of the prior art $\left(\S \S 3\right.$ and 4 , German Patent Act) ${ }^{7}$ If the examination of a patent application reveals novelty, inventive activity and commercial applicability and the formal requirements of the application are fulfilled, the patent right will be granted.

In 1978 the PCT entered into force. ${ }^{8}$ A PCT application allows an applicant to file one international application ("international phase") in a process to seek patent protection in multiple contracting states named in the application ("National Phase"). A PCT application can be filed up to twelve months after the priority date and is submitted to the relevant national patent office or to the European office (Art.

\footnotetext{
${ }^{5}$ There are special chambers at district courts which are exclusively responsible for dealing with IPR suits. They are distributed throughout a region in order to give all potential plaintiffs the chance to file a suit in the vicinity of the infringer.

${ }^{6}$ This calculation is based on the application and granting information contained in the PATDPA database described in section 4.2. There is a large variation among the years. Patent applications submitted in the late 1980s to the mid-1990s had an average granting probability of more than 70 percent, starting at 41 percent in 1978 and increasing to 71 percent in 1988. From 1995 to 1999 the granting rate decreased to 48 percent, which was partly caused by the grant lag of about 3.2 years.

${ }^{7}$ In Germany, it is possible to apply for a petty patent or utility patent. These patents have lower requirements for the inventive step $(\S 1$, Utility Patent Act). In contrast to the inventive activity necessary for a regular patent grant, the inventive step for an utility patent requires a less detailed examination. However, in terms of enforcement the same rules apply as to the regular patents.

${ }^{8}$ The PCT is a multilateral treaty that was concluded in Washington in 1970. It is administered by the International Bureau of the World Intellectual Property Organization (WIPO), whose headquarters are in Geneva (Switzerland). As of the beginning of 2004, 123 contracting states provide the possibility of applying for a PCT patent.
} 
10 PCT). Art. 15 PCT specifies how the first international search is to be conducted. The advantages of PCT applications are that the applicant files one application - the international application - in one place and in one language, paying one initial set of fees; this international application also has the effect of a national or regional application. Without the PCT, the applicant would have to file separately for each country. In addition, at the beginning of a patent's life - the "international phase" - its applicant does not face all of the translation costs and application fees at once. They are due when the application enters its respective "national phase". 9

At the same time, in 1978, the European Patent Organization started to work actively with the European Patent Office (EPO) in Munich. ${ }^{10}$ The European procedure for patent application, examination, and granting is very similar to that of Germany. At the applicant's formal request, an examination concerning the novelty and inventive step determines whether the prerequisites for patentability are fulfilled (Art 92, European Patent Convention, EPC). The examination report is a formal statement of the legal executive authority and serves as the basis for the granting decision. A European application names the member states in which patent protection is sought. In those designated states, a European patent grant becomes a national right.

Both the European and German patent systems provide the opportunity to oppose a patent grant, although the post-granting time frames differ. These requests are decided upon by specialized opposition boards at the patent offices (Art. 99, European Patent Act; $§ 59$, German Patent Act). ${ }^{11}$ In Germany, invalidity suits as well as appeals against decisions on opposition are heard at the Federal Patent Court in Munich (§ 81, German Patent Act).

Annulment suits are also part of the patent system. According to $\S 82$, German Patent Act, an annulment suit has to be filed at the the Federal Patent Court. European patent grants for Germany become regular German patent rights. Because of this, annulment suits against these grants must be filed at the German Federal Patent Court. For patents valid for the German market, issues of infringement and license disputes are left to the specialized district courts of civil law. These issues are completely separate from questions of patent validity. If property rights are in force, they are civil rights and civil law therefore applies in cases of their infringement. Enforcement procedures such as infringement or license disputes must be brought before the relevant district court of first instance. Patents are presumed to be valid by the judges involved. As von Meibom und Pitz (1996) point out, the German district courts have "no power to revoke the patent or to alter the claims of the patent." The jurisdictional responsibility for patent infringement cases is given to 13 district courts in Germany. More than $80 \%$ of all cases in Germany are covered by the district courts in Düsseldorf, Munich, and Mannheim. Hamburg, Frankfurt and Braunschweig can be considered experienced courts as well even though a fairly low number of cases are filed there. The plaintiff can almost arbitrarily choose the location for filing the suit. He or she can sue either at the infringer's domestic location of business or in the jurisdictional area where the infringement took place. Therefore, a potential plaintiff will search for a forum where he or she expects the highest benefit in terms of damages but also in terms of winning probability. This "forum shopping" is also be influenced by differences in technical qualification and experience of judges at various district courts.

The course of patent infringement suits is determined by the German Code of Civil Procedure. Nevertheless, this can differ from one district court to the next with respect to the time table of actions, another reason for forum shopping. An IPR case starts when the plaintiff issues a statement of claim including the names of the parties, the details of the infringing action, and the particulars of the property right in question. It also specifies the remedy requested, including all costs and damages. The court serves the statement of claim to the defendant, who then has the chance to respond to the allegation. A common means of defense is to present a nullity claim or an opposition which is often combined with a request to postpone the litigation procedure. ${ }^{12}$ The court forms expectations regarding the outcome of these means

\footnotetext{
${ }^{9}$ See Thumm for a comprehensive description of IPR systems.

${ }^{10}$ The European Patent Office grants European patents for the contracting states to the European Patent Convention, which was signed in Munich on 5 October 1973 and entered into force on 7 October 1977.

${ }^{11}$ An opposition against a granted German patent must be filed within three months of the grant's announcement ( $\S 59$ German Patent Act). For a European patent, third-party opposition is possible up to nine months after the patent grant is published (Art. 99, European Patent Convention).

${ }^{12}$ Case evidence shows that in around 50 percent of the cases, an opposition or a nullity suit had been filed as a means of defense. See von Meibom und Pitz (1996) for further procedural details.
} 
of defense and decide whether the legal procedure should be postponed until the Federal Patent Court or the DPMA has decided on the validity of the patent. Evidence is derived mainly from documents, witnesses, and independent experts. The parties are legally bound to deliver all relevant information; there is, however no discovery. The plaintiff in particular is required to exercise due diligence in fully investigating the potential infringement. If the parties are unable to come to a settlement agreement, the judge orders an oral hearing and renders a judgement. The judgement is either condemnation or partial condemnation of the defendant according to the plaintiff's requests or a dismissal of the lawsuit. In case of condemnation, the remedies can be injunction, accounting for unlawful profits, or damages. In those cases, the infringer is obliged to stop the infringing action, provide all necessary information for calculation of the damages and eventually pay them. ${ }^{13}$

In cases of urgency and risk of high and irreparable losses, the patentee may apply for a preliminary injunction ( $\S \S 934$ and 940, German Code of Civil Procedure). This must be done promptly after the infringement has been detected. ${ }^{14}$ Moreover, the patentee must issue a clear statement that this urgent injunction would prevent him or her from suffering large losses. If the injunction is granted, the infringer will be enjoined from continuing his or her infringing activities (§ 139 German Patent Act). ${ }^{15}$

Two types of expenses are relevant in most cases: court costs and attorney costs. Both are strongly related to the jurisdictional value of the case, which is set by the court after the letter of claims is filed. The court estimates the jurisdictional value considering the value of the invention and the size of the parties involved. ${ }^{16}$. The judge takes into account a fairly rough estimate of the patent holder's recorded sales with the patented invention. Both court costs and recoverable attorney expenses depend on the jurisdictional value based on a fee schedule. According to the applicable British rule, the losing party must pay all of the winning party's court costs, recoverable attorney costs, and expenses for expertise of the winning party, as well as its own expenses.

\section{Aspects of decisions on infringement, litigation and settle- ment}

\subsection{Theoretical framework}

Theoretical work on the determinants of patent litigation indicates that the sample of litigation cases is not a random selection of all possible suits (Priest und Klein 1984, Bebchuk 1984, Katz 1987). Following the argumentation in the selection model of Priest und Klein (1984), all determinants of settlement and litigation are purely economic. Their model indicates that parties will settle when their expectations regarding the quality of the dispute and their involved stakes are similar. ${ }^{17}$ Furthermore, the litigation rate will increase (and the settlement rate will decrease) when the cost of settlement is high relative to the litigation cost. The authors assume that the expectations the parties have of the outcome and their actual gains from the litigation suit diverge while the information on the stakes and the probability of winning is distributed symmetrically. These data include the expected costs of the court decisions, the information that parties possess on the likelihood of success, the reputation gains or losses and the direct costs of a trial. Katz (1987) also observed that the demand of litigation is determined by the relation of the gains of a dispute relative to its cost.

Subsequent models allow for different information allocations and distributions of knowledge among the parties and assume asymmetric and/or incomplete information. For example, Meurer (1989) draws

\footnotetext{
${ }^{13}$ Usually, judges declare all remedies. But it can be that only condemnation is declared, or damages without accounting have to be paid.

${ }^{14}$ Urgency is assumed by the courts only if plaintiff files for preliminary injunction without undue delay after obtaining knowledge of an infringement. The undue delay is subject to interpretation. The Munich I district court considers longer than four weeks undue, and all other patent district courts consider more than six months. See Pitz (1999) and Marshall (2000)for more details.

${ }^{15}$ See Körner (1984).

${ }^{16}$ See Stauder (1989), p. 62.

${ }^{17}$ This is be the case when the true value of the dispute lies far from the decision standard of the court, whether in favor of the plaintiff or the defendant.
} 
conclusions about litigation and settlement decisions in different information situations and different allocation rules. Bebchuk (1984) developed a model based on the theory that parties make decisions with incomplete and asymmetric information. Waldfogel (1998) clearly differentiates between the two main underlying types of litigation models, asymmetric information and diverging expectation. Spier (1994) extends the analysis toward a sequential game with asymmetric information. ${ }^{18}$ However, the approach of Priest und Klein (1984) has become the standard model in economic literature on patent infringement and challenge cases, since information in IP suits flows through documents and electronic files relatively easily and is associated with low costs. Therefore, symmetric information is a reasonable assumption in this case. Moreover, the practice of law is very internationalized and thus not so great advantages for domestically owned firms over parties from abroad concerning information arise. Most of the empirical research on the enforcement of property rights and the determinants of patent litigation base their results on the same assumptions to model the conditions under which litigation cases will be brought to trial (Lanjouw und Schankerman 2001, 2003, Lanjouw und Lerner 2001, Lanjouw und Lerner 1998, Ziedonis 2003, Somaya 2003). The same basic idea was also applied by Harhoff und Reitzig (2004) to a model of opposition against pharmaceutical and biotechnology patents at the EPO.

One drawback of the models above is that they start their analysis after the suit has already been filed. This approach disregards the decision of the potential infringer to enter the market with potential imitation as well as the decision of the patentee to file suit against a detected infringer. The problem with analyzing a selection of patent suits is that it is not possible to observe the population of all infringed patents in reference to the potential base of all possible suits. Investigations of litigation always lack observation of the infringement rate. To the best of my knowledge, neither in theoretical literature nor in empirical investigations this problem has been solved. ${ }^{19}$ All results regarding the probability of patent litigation are actually statements about the (conditional) probability of a litigation suit given that the patent has been infringed. ${ }^{20}$

The general paths of enforcing a property right are shown in figure 1 according to the legal rules outlined in section 2. First, a potential infringement of a property right occurs and the patentee considers a possible reaction. The patentee has the choice between two alternatives. The first is to make a settlement offer in order to reach an agreement out of court. This offer usually contains a license agreement. If it is accepted the matter is settled Second, the patentee can file a statement of claims in order to start a legal action. A legal action can be a regular suit or a request for preliminary injunction. ${ }^{21}$ Modelling the decision to file a suit I do not distinguish between filing an ordinary suit and a preliminary injunction because in the German system it is expected to file an ordinary suit in order to reach a final solution after the injunction has been granted.

In the following I analyze the decision problem of the parties in a framework presented by Priest und Klein (1984). The patentee and the infringer decide on whether to litigate or to settle. I assume complete

\footnotetext{
${ }^{18}$ Unfortunately, the data available for this study do not allow the derivation statements about the distribution of information.

${ }^{19}$ Lanjouw und Schankerman (2003) mention this problem in their study and argue: "If a patent dispute is settled before a suit is filed, we do not observe the dispute in the data. Thus low filing rates can either reflect low rates of infringement or high probability of pre-suit settlement."(p.149).

${ }^{20}$ Crampes und Langinier (2002) consider a two-stage game involving the decisions of the potential entrant to infringe and of the patentee to sue explicitly. From their model they derive predictions about rate of infringement (in the sense of market entry). Frequency of infringing entry is negatively correlated with the amount of the penalty for infringement and usually also with settlement cost, efficiency of legal procedures, and probability of infringement identification. Within their framework, the bargaining power of the patent holder has no unambiguous impact on the frequency of entry. The predictions of Crampes und Langinier are in the line with earlier results of theoretical literature on litigation and settlement (Perloff und Rubinfeld 1987, Ordover und Rubinstein 1986, P'ng 1983, Cooter und Rubinfeld 1989.)

${ }^{21}$ Lanjouw und Lerner (2001) apply the request of a preliminary injunction as a second, separate way to start an action before court. The injunction process can have a substantial impact on the payoffs. The patentee has to make clear that in order for he or she to avoid considerable harm a fast decision is necessary. Additionally, he or she has to make the claims clear. Both are very costly in terms of attorney expenses. For a defendant (or the potential infringer) the preliminary injunction imposes a significant danger because it can nullify all or a large part of his or her business (Lanjouw und Lerner 2001)
} 
Abbildung 1: Structure of a Patent Infringement Dispute

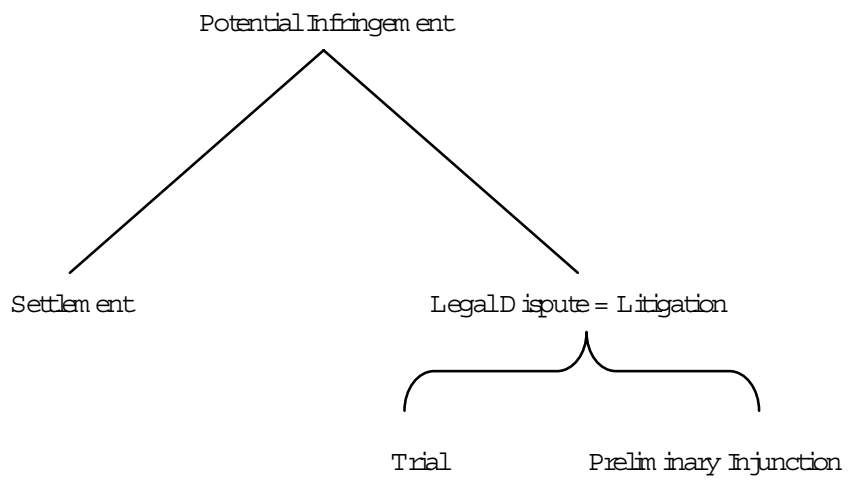

and symmetric information on all facts necessary to form expectations of the probabilities of granting and winning as well as the payoffs and costs of the dispute. ${ }^{22}$ However, due to idiosyncracies parties do not necessarily expect the same winning probability or similar values. Parties will go to trial if their expected return net of legal costs is equal or larger than the expected outcome of a settlement. Thresholds of the patentee and the litigant have the following form:

$$
\begin{array}{rlr}
p_{p l}[V+D(V)]+\left(1-p_{p l}\right)\left[\frac{\delta}{2} V-C(V)\right] & \geq(1+\alpha) \frac{\delta}{2} V & \text { Patentee } \\
-p_{i}[D(V)+C(V)]+\left(1-p_{i}\right)\left[\frac{\delta}{2} V+C(V)\right] & \geq(1-\alpha) \frac{\delta}{2} V & \text { Litigant }
\end{array}
$$

Parties form expectations regarding the probability that the plaintiff (patentee) will prevail. Therefore, $p_{p l}$ and $p_{i}$ are expected probabilities of the plaintiff and the infringer, respectively. In the case where the patentee prevails, he or she earns $V$ and is paid damages $D(V) \cdot{ }^{23} V$ is the profit the patentee exoects to gain by exploiting the patent alone (i.e., without infringement or license agreement). With probability $1-p$ the court votes against the patentee and he or she has to pay both his or her own legal expenses and those of the prevailing defendant. ${ }^{24}$ In this case, more than one company uses the patented innovation and $\delta$ reflects the extent to which the respected industry profit is lowered.

The right hand sides of (1) and (2) show the settlement value for the patentee and the infringer, respectively. In order to avoid an infringement suit the plaintiff allowed the competitor the use the patented innovation and received royalty payments for the production of the patented innovation. A license agreement will enhance the profit for the patentee by the license fee $\alpha$ on which the parties agreed. Such a license agreement may include price and output restrictions for the competitor, and it may also define the explicit license fees to be paid to the patentee. ${ }^{25}$ The parameter $\alpha$ is the share of profit the competitor has to give up to the patentee and $(1-\alpha) \frac{\delta}{2} V$ the settlement payoff of the potential infringer. ${ }^{26} V$ is a function

\footnotetext{
${ }^{22}$ I cannot completely exclude the possibility of asymmetric information on all matters pertaining to the litigation process and its outcome, such as strength of the patent right and extent of the patent protection which will be elucidated by the judges during the trial. Different knowledge about the applicability of the patented innovation and market conditions can also affect the decision to litigate. But the information about the technical details of the patent, the main economic facts about the litigants and the understanding of the jurisdictional system are available to all parties.

${ }^{23}$ There are three main methods of calculating damages, all of which depend on the value the patent creates on the market (Reitzig et al. 2003). Additionally, the time length of infringement and the time left on the patent is enclosed within the expectations the parties make.

${ }^{24}$ According to the British rule of cost allocation the losing party has to bear all legal costs. However, in jurisdictional practice not all attorney expenses are taxable.

${ }^{25} \mathrm{I}$ assume that there is no strong antitrust regime.

${ }^{26}$ It is also possible that the patentee will not proceed to trial even if the potential infringer rejects a settlement offer. The license fee in this case is zero.
} 
of the characteristics of the patent $x_{p}$, the characteristics of the firm, $x_{p l}$ and $x_{i}, V=V\left(x_{p}, x_{p l}, x_{i}\right)$. There exist two types of legal costs. The first type are court costs $c$ which do not depend on the patentee's opportunities on the financial market or on his efforts in the case. The second type is the attorney cost and depends heavily on the efforts one party undertakes in the suit and on the financial conditions it faces on the market in funding these activities. By law, all legal costs must be proportional to the size of the case by a factor smaller than one. The size of the case is the loss the patentee is expected to suffer when the potential infringer uses the invention without permission during the time of dispute and is calculated as difference between the possible monopoly profit and the patentee's fraction of the non-settlement profit, $\left(V-\frac{1}{2} \delta V\right)$.

\subsection{Hypotheses on the Determinants of Patent Litigation}

From (1) and (2) it is to be seen that the probability of patent litigation depends on the profit $V$ the parties expect to earn by using the patented innovation. I consider the profit $V$ in the model as a close correlate to the value of the patent which is a wider concept including the strategic capacity as well as the signaling and blocking power of the patent. Thresholds (1) and (2) reveal clearly a positive impact of the value of a patent on the incentives to enforce it (Lanjouw und Schankerman 2001, 2003). With increasing value of the patent for both the patentee and the infringer the direct incentive to proceed to trial rather than settle increases.

A growing value also raises the probability of an infringement, which leads implicitly to a higher probability of litigation. As mentioned before, the probability of infringement is not observable; the only evidence, offered by Harhoff und Reitzig (2004) shows that the probability of opposition as an early type of attack against a granted patent increases with the value of the patent. In the following I derive hypotheses on how these characteristics influence the probability of a patent litigation suit. The expected winning probabilities $p_{p l}$ and $p_{i}$ also depend on the characteristics of patentees and the information available to them.

\section{Characteristics of the patent}

The impact the characteristics of patent have on the probability of litigation is mainly due to their correlation with the value of the patent. Patents are heterogenous and supply different levels of additional profit to companies through the original protection function and strategic functions (Somaya 2003). The value a single patent has for its patentee is not observable. The impact that patent portfolios or patent stocks have on firm value, profits, and sales is hard to identify from survey data (Harhoff et al..

The patent applicant suggests patents which should be included as references to the prior art. However, the examiner (either of the EPO or the DPMA) makes the ultimate decision on what patents will be included as backward citations. In contrast, for a U.S. application the applicant is requested to name all references to the state of the art using patent or non-patent literature, which leads to more citations and to quoting publications which are only tenuously linked to the applied invention. Michel und Bettels (2001) emphasize that US citations appear to be more a documentary search than a patentability search. The references to earlier patents in the German and European system mark the boundaries of patentability and the bases the invention builds on. They are used to substantiate the patentability for which novelty and inventive activity is necessary. This function of citations implies that the number of citations received (forward citations) play a similar role to that of references in scientific publications as an indicator for the importance of the patent. Traijtenberg (1990) supported this argumentation considerably and Harhoff et al. (2003a) provided more broad evidence of the correlation between patent value and citations received in subsequent patent applications. Using the information the citing patents provide, citations can be used as ingredients in the construction of measures for "originality" and "generality" (Hall et al. 2001). Even though the forward citation can point to further development and depreciation of the former invention, the value enhancing effect should be dominant.

H1: Patents which received a large number of forward citations in subsequent patent applications have ceteris paribus (c.p.) a higher probability of litigation than less cited patents. 
References made to prior patents in both the EPO and DPMA patent applications reflect the state of the art - the scope. On the one hand, they indicate previously granted patents that pose a potential threat because they are similar to the invention named in the patent application under consideration and may restrict it. On the other hand, scope is confirmed to be significantly positive correlated with the monetary value of German patents (Harhoff et al. 2003). These two functions of citations are not distinguishable and have a positive effect on the probability of litigation. Lanjouw und Schankerman (2003) argue that a large number of references in the patent application indicates a well-developed technology with less uncertainty than newly developed technologies, making litigation less likely. This effect depends highly on the specific tendnecy of the U.S. system to cite as much as possible. Harhoff und Reitzig (2004) find the total number of backward citations in EPO applications to have no significant effect on the probability of opposition. The U.S.--based study of Lanjouw und Schankerman (2001) reports no significant effect of backward citations per claim, whereas using an updated data set they show a negative effect(Lanjouw und Schankerman 2003).

H2: The effect of backward citation on the probability of litigation is, ex ante, not clear. It depends on the relative strength of the value enhancement and restricting effects of backward citation with respect to the diminishment of uncertainty.

A patentee can file patent applications for the same subject matter in more than one jurisdiction, building a patent family. Within the one year of priority he or she can file exactly the same patent at certain patent offices while still fulfilling the requirement of novelty. Putnam (1996) first introduced the number of such jurisdictions representing family size as a value correlate of patents because it is associated with considerable costs of application and translation. It is a suitabke variable because it reflects the patent holder's private estimation of the patent's value.

H3: The number of different jurisdictions patent protection is sought in (family size) is, c.p., positively correlated with the probability of litigation.

A patent claim defines in words the boundaries of an invention so that the public will know what the invention is and can avoid infringing it. A patent usually comprises a bundle of independent principle claims which define the basic elements of the invention. Additional subordinate claims describe the invention in more detail. For the value of the patent the principle claims have a higher relevance than the subordinate claims. For broad patents indicated by a high number of total claims, an infringement is more likely. Since probability of litigation is conditioned on the probability of being infringed, c.p., probability of litigation depends on number of claims. Positive relationships between number of claims and probability of a patent being subject to a dispute are found in Lanjouw und Schankerman (2003), Graham et al. (2003), and Harhoff und Reitzig (2004).

H4: The number of claims has c.p. a positive impact on the probability of patent litigation.

As I explained in section 2 there are three different ways of seeking protection in more than one country. First, a patentee can apply in each country at its domestic patent office. Second, the European Patent Office can provide protection within any or all of the member states of the European Patent Convention via just one application. Applying per PCT application is the third way. It offers patent protection in all member states of the PCT. In a study by Thumm (2000) the "road of application" is used to indicate the importance an invention has for the inventor or applicant. PCT applications are similar to EPO patents; they seek protection in more then one jurisdiction within the member states. I assume that facing the higher cost of a PCT or EPO application compared to a DPMA application the applicant expects compensation through higher profits and this values the patent more highly.

H5: Patents which are applied for through the international path via PCT have, c.p., a higher probability of being litigated than patents applied at the EPO or at the German patent office. The application path via EPO leads to a higher probability of litigation than that of the German patent office. 
Patents issued by the EPO or the DPMA can be subject to opposition. Any third party can file such a procedure, claiming that the invention is not new or the inventive step is not signigficant enough. An opposition is an official act at the patent office that seeks to declare a patent invalid or to amend it. ${ }^{27}$ If the potentially infringing party is opposing the patent before the suit begins it seems likely that this party has an interest in using the invention itself and not in leaving the right to the patentee. One reason for such an interest could be that the opposing (and potentially infringing) party has made a similar invention. Another reason might be that the expected value of the protected invention is so high that it is worth opposing and later infringing in order to appropriate at least some of the payoffs of the protected innovation. Harhoff et al. (2003a) found that a patents which have defeated an opposition procedure are significantly more valuable than those patents which have not been not attacked. This finding was strengthened by the analysis of Harhoff und Reitzig (2004), which shows that opposed EPO patents in biotechnology and pharmaceuticals are generally more valuable, than those which were not opposed when measured by several value indicators. On the one hand a higher expected value of a patent attracts more exploitive interests and leads to a higher probability of legal dispute. On the other hand, a patent which has faced opposition becomes more valuable because it indicates a stronger patent right; this will increase the plaintiff's expectations about the probability of winning the case, $p_{p l}$. I expect that both effects lead to a positive impact on the probability of litigation (Graham et al. 2003).

H6: Patents which faced an opposition procedure after granting are c.p. more likely to be involved in a subsequent litigation procedure.

\section{Characteristics of the patentee}

Main findings for the U.S. show that the size of the patentee (Lanjouw und Schankerman 2003, Harhoff und Reitzig 2004) and the relative size of the parties (Somaya, 2003) matters considerably to the probability of being involved in a patent dispute. Large firms are generally less likely to be involved in litigation suits than smaller ones. A reason might be that large firms estimate the value of an invention differently in relation to and their overall profits. In most empirical studies, size is measured by technological size (number of previous patents granted to the patentee). As indicators for the absolute size served mainly dummies for listed and unlisted companies and dummies for individuals. Accounting figures such as turnover or number of employees are rarely available (Lanjouw und Schankerman 2003, Harhoff und Reitzig 2004, Graham und Somaya 2004). It is generally assumed that economically large firms tend to have more patents than small firms. A financially strong firm has a higher potential to threaten a suit being better equipped to reconcile all included costs over a longer period of time.

H7: Large firms face, c.p., a smaller probability of patent litigation than small ones.

Companies with a large portfolio of previous patents are more experienced in enforcing their rights. Additionally, firms with a large portfolio of similar patents have more opportunities to keep $\alpha$ small and to offer cross licensing agreements for settlement. The argument that repeated interaction of firms with large patent portfolios leads to a higher threat point in settlement bargaining is made by Lanjouw und Schankerman (2003). However, this is of importance only in case when the financial markets are incomplete. Companies with a large portfolio of patents which are probably related to the patent in question are likely to be involved in more potential infringement and litigation disputes as well as more license bargaining. It is not clear whether the experience in bargaining, the reputation gained through prior disputes, or the high expected costs of repeated disputes lead to smaller probability of litigation for these companies.

H8: Firms with a large number of previously granted patents (a large patent portfolio) are, c.p., less likely to be involved in patent litigation suits. The effect diminishes in proportion to an increasing portfolio size. I expect an U-shaped relationship

\footnotetext{
${ }^{27}$ See Harhoff und Reitzig (2004) and for a detailed description of the opposition procedure.
} 
Because of individual patentee's tendnecy to be personally involved in the enforcement of "their patent", I expect a bias towards more litigation suits when these patent owners are involved. Individuals tend to be more optimistic in evaluating the profits of a patented innovation (Astebro 2003). According to the model outlined above this would lead to a higher risk of litigation for individuals when compared to companies. A significantly higher probability of domestic individuals suing potential infringers is also a stable stylized fact and is displayed in the above cited studies on the U.S. This is partly due to larger relative stakes of individuals. Individuals patenting software innovations in the U.S. were found by Graham und Somaya (2004) to be more litigious than companies. Lanjouw und Schankerman (2003) show mixed evidence: for domestic individuals a positive effect but the opposite for foreign individual patent owners. I also expect that individuals are more likely to be involved in patent litigation than companies.

H9: Individuals are, c.p., more likely to litigate than companies.

I expect that the origin of the patentee matters due to different costs of aquiring access to information. The probability of litigation should be higher for Germans, compared to foreign patent owners. Regarding foreigners, I expect European patentees to be more often involved in patent litigation suits than owners from non-European countries because of the lower expected costs (Harhoff und Reitzig 2004). Foreign patentees have per se the same access to information regarding the patented invention. But, the cost related to translation and to the attorney for the German jurisdictional system are considerable and lower their propensity to sue at a German district court.

\section{Data}

\subsection{Court data collection}

For the empirical analysis of patent litigation cases, I used a database extracted from files in court archives. In Germany computerized data are not available, neither on litigation in general nor on patent litigation in particular. All large district courts with specialized chambers for IPR suits ${ }^{28}$ were asked for access to their archives. Two of the three most important district courts -Duesseldorf, Mannheimagreed to give access to the written case records. Stauder (1989) found that more than 60 percent of the patent and utility cases are finished within their second year and $95 \%$ after six years. Around one year is necessary for the court of first instance. Since the archives contain only records of finished cases, I chose the filing years 1993-1995 at the courts. These filing cohorts are likely to catch as many finished cases as possible and are not too far in the past to match comprehensive information about the parties with information from other databases. ${ }^{29}$ Virtually all cases filed during this period of time are included within the data set. In Mannheim data collection lasted from May 1999 to July 1999. In Düsseldorf it lasted from October 1999 to February 2000.

Even though the chambers at the district courts are specialized, there is a wide range of different legal arguments treated at those chambers: disputes over general contracts, license suits, and IPR cases including patents, utility patents, copyrights, and trademarks. For IPR cases, not only infringement is a topic of legal disputes, but all kinds of contract issues must be decided on. Therefore, it was necessary to identify the patent and utility infringement cases among all cases filed at those chambers. For the purpose of this research, I chose the legal rights of patents and utility patents because they are relatively strong compared to trademarks and copyrights and they identify technological inventions based on R\&D efforts. The procedures for legal disputes about infringement are very similar for both types of property right. The subject line on the front page of the files served as the main indicator. I searched for words and phrases such as "patent," "patent infringement," "utility patent," "injunction," "preliminary injunction," "presentation of accounts," "license agreement," and "employee invention." The first screening revealed about 950 cases of infringement. A second screening, reading the statement of claim and the defendant's

\footnotetext{
${ }^{28}$ Mannheim, Düsseldorf, Munich, Frankfurt

${ }^{29} \mathrm{~A}$ cohort contains patents with the same year of application.
} 
answers, disclosed whether the subject matter was really an infringing action. I kept only clear cases of patent and utility infringement. For the analysis, I included both requests for preliminary injunction and regular filings in the investigation. I discarded all suits regarding disputes over license contracts, legal arguments about compensation of employees' inventions, and other cases with patents and utility patents involved but where no infringement took place. After the second screening 715 infringement cases were left within the sample. By definition of the jurisdictional responsibility, challenge suits are not treated at the district courts. However, there are suits dealing with license disputes where patent claims and license contracts are in question, suits dealing with unauthorized warnings against infringers who actually did not infringe, or suits dealing with advertising with patent rights which are not actually covered by patent claims. Those types are similar to challenge suits but are heard by the civil court. For this reason I maintained those proceedings within the data set. For the third step of the detailed investigation, 715 cases of pure patent or utility litigation had to be screened meticulously. The correspondence of the parties, including the statement of claims and the response of the defendant, was checked. This process yielded information about the requested claims and the arguments of the parties. The court decisions and rulings revealed the outcome and the costs of the cases. ${ }^{30}$

The information extracted from the written case files was divided into three main categories: the proceedings of the suit, the parties, and the patent at issue. The first category covers a brief description of the stages of the infringement case. It includes the dates of the filing, the oral hearing, and the ruling. Almost all case files reported the outcomes, including the outcomes of any first and second appeals. Cost figures were also collected. Additionally, paid damages were added to the costs. The second category covers the names and the locations of the parties involved in the trial. At least one party was located within the jurisdiction of the court. The third category covers information on the patents, such as the age of the patent at time of filing as well as the field of technology (IPC).

The amount of information about the patents kept in the court records differs between the two courts. In Mannheim, the records normally include the patent document or the disclosure as well as witnesses' documents and expert's reports. At the district court in Düsseldorf, only the statement of claim, the subsequent correspondence between the parties and the court, and the judgement of the court are kept in the permanent files.

\subsection{Public data}

In order to complete the information about the patents involved in the disputes, data from the German Patent Office (DPA) and the European Patent Office (EPO) were added. Information on application dates, granting dates, IPC classifications, and the applicants and inventors are available from the databases PATDPA and EPOLINE. PATDPA is the database of the German Patent Office and lists all patent applications with all information included in the patent document. Additionally, all bibliographic data such as fee payments, oppositions and their results, changes of the patentee, and the lapsing of the patent in the public domain are viewable in this file. PATDPA contains around 2.5 million patents and utility patent. It covers patent data from 1976 until 1998. Beginning from 1978, the electronic form contains reliable information on patents and utilities. But still the information on the renewal data are not complete. A similar database, ELPAC, is available at the European Patent office. It includes all patent applications submitted to the EPO with roughly the same variables, encompassing 1.2 million patent applications since 1978. The important information about backward and forward citations was extracted by searching the complete databases. ${ }^{31}$

As mentioned above, the records of the Regional Court in Mannheim normally include the patent documents. with information about the patent, such as the name of the applicant, IPC classification, dates of application, granting, an publishing, and so on. For the Düsseldorf records, the statement of claims contains most of this information, but often the records are incomplete in this regard. A patent number,

\footnotetext{
${ }^{30}$ The appendix contains the detailed form I used to record all the information I extracted from the written case files.

${ }^{31} \mathrm{~A}$ detailed description of the creation of the citation data file and the correction for truncation following Hall et al. (2000) is given in Section 4.4 .
} 
either from the EPO or the DPA, was accessible in $95 \%$ of the suits. In cases where patent numbers could be matched, the information was updated by using the PATDPA database or the ELPAC database. ${ }^{32}$

Since an official business register does not exist for Germany, I added the complementary information for corporations using the database of the most important German credit rating agency, the Verband der Vereine für Creditreform (Creditreform data) in Neuss. Merging these data with the litigation data gives us a more detailed picture of the corporations involved. Industry codes according to the European NACE classification were added as well as firm size measured by the number of employees.

\subsection{Creation of the control group}

For an investigation of the differences between patents litigated and those not, it is necessary to create a control group of patents. Therefore I have selected an appropriate data set from the population of all German patents and European granted patents from 1978 to $1995 .{ }^{33}$ I have stratified the control group by the year of application and the main IPC classification at the four-digit level. For each patent in the group of litigated patents, one matched patent was drawn randomly from the universe of German and European patents. When randomly chosen patents are used as the control group, matched patents means that those were not subject of a legal litigation suit. There is still a probability that a patent chosen for the control group was subject to an earlier or later dispute or to a dispute at one of the other nine district courts. But this probability is fairly small (about one percent) and can be disregarded. I could not find comprehensive data in the database for patents in the group of litigated patents which had an application date prior to 1978. To ensure a one-to-one match, I excluded those patents from the investigation group. Finally, the sample of litigated patents contains 824 patents with application dates from 1978 to 1993 . Finally, the reference group of non-litigated patents consists of 824 patents. All relevant variables including citation data and information on patentees and technology fields are included for these patents.

\subsection{Variables}

In section 3.2 I introduced the theoretical determinants of probability of litigation. In the following I link them to a set of independent variables consisting of those which are related to the characteristics of the patent as an invention, those which describe the patentee, and those which are related to the market situation and conditions for innovative activity. Table 1 shows descriptive statistics for the variables I used in the analysis. The first block contains the patent characteristics. The characteristics of the patent holder are displayed in the second block.

\section{Patent characteristics}

For an analysis of forward citations I searched the patent databases PATDPA (FORW_CIT_D) and ELPAC (FORW_CIT_E) thoroughly and counted the number of subsequent patent applications which cite the investigated patent as prior invention. I truncated the number of forward citations at the first filing year 1993. Furthermore, it is not certain that the full number of citations received is documented in the PATDPA even for the oldest patents with application dates in the early 1970s. To correct for this truncation bias I used the method of "fixed effects" as described in detail in Hall et al. (2002). The underlying assumption of this approach is that all differences in the citation intensities over time are due to artifacts. Citation behavior does not change over time and the number of forward citations per patent and per cohort is constant. Annual effects are eliminated by dividing the number of forward citations of a patent by the mean of forward citations of its cohort. I used this weighted forward citation in the analysis.

\footnotetext{
${ }^{32}$ The concomitance of the European and German system and their interdependence is fact to be considered in the variable definition especially creating citation data.

${ }^{33}$ Since All European patents granted for Germany are encompassed in PATDPA, I have drawn the matched patents from the PATDPA solely. Though some additional information came from other data bases such as ELPAC and EPOLINE.
} 
In the samples of both litigated and unlitigated patents are 438 patents that were originally filed at the EPO. The other 1,210 were originally applied for at the DPMA. Reliable information on forward citation was available only at the original patent office. By reason of this lack of data I combined both sources of information and removed double counts (FORW_CIT_D+E). Tables 2 and 3 indicate the main properties of these citation variables. It contains the disentangled means for references made and citations received at the DPMA (FORW_CIT_D) and at the EPO (FORW_CIT_E) as well as the combined figures (FORW_CIT_D+E).

First, I observe table 2, column 5 to compare the sample means of the forward citations. On average, an original European patent in the sample is cited in 1.877 subsequent European patent applications. Surprisingly, this number is significantly smaller than for German subsequent applications. Original German applications in the sample have on average 2.172 forward citations. One reason might be that patents valid in Germany are more frequently cited at the DPMA because it is the relevant market. For European patent citations patents from other EPC member states are more important in respect to the first to file rule. In all cases litigated patents are more frequently cited than those unlitigated, which is expected in H1. On average, the number of the combined forward citations is 2.33, while litigated patents had received 2.8 times more forward citations than unlitigated patents (table 1). ${ }^{34}$

Now I turn to the number of backward citations, which I display in detail in table 3. A problem similar to that which presented itself regarding forward citations occurred for this variable as well. For the 1,210 patents originally filed at the DPMA I used citations from the DPMA publication (BACKW_CIT_D). For the 438 applications which were made solely at the EPO with designation to Germany I implemented the backward citations from EPO (BACKW_CIT E). While Michel und Bettels (2001) stress the diversity in citation attitudes among the triad patent jurisdictions (US, EPO, JP), there are also differences between the EPO and the DPMA. Again, I use both variables parallel (BACKW_CIT_D+E) because, for original EPO patents, only the references in the EPO publications documents are available (BACKW_CIT_E). While the average of BACKW_CIT_D is 2.401, the mean of BACKW_CIT_E is 4.559. The difference is statistically significant. In general, litigated patents tend to cite more references to prior patents than unlitigated patents by a factor of 1.5. However this is driven by backward citations of the original German applications. For patents that were applied for at the European Patent Office, BACKW_CIT_EPO is not significantly different between litigated or unlitigated patents.$^{35}$

For the following variables, information is almost uniquely available both for original German patents and original European patents and the description is consolidated in table 1. The number of claims was received directly from the patent documents which can be downloaded from the databases (CLAIMS). I calculated the number of independent claims. In this study the number of claims is used as a better measure of patent breadth compared to the number of IPC subclasses a patent can be assigned to. The number of claims differs between the groups. While 9.6 claims were filed on average across the entire sample, the patents not involved in litigation had an average of 8.6 claims and the litigated patents 10.5.

Patent data bases usually contain a set of variables which reveal family information. FAMILY_SIZE is defined as the number of jurisdictions in which patent protection was sought. It conforms to the definition of family size used by Putnam (1996). After removing double counts this variable was directly obtained from PATDPA to be used in this analysis. At the EPO the variable for family size is not readily available; the number of designated states includes only states which are members of the European Patent Organization and does not include jurisdictions such as the U.S. or Japan. The average family size of litigated patents differs significantly from that of unlitigated patents (5.6 and 4.7).

Patents which were filed via the PCT application path (PCT_APPL) are rare within the sample of litigated patents. The number of PCT application actually remained very small until the end of the 1980s and grew at the beginning of the 90s. Generally, only 1.7 per cent of patents were sought via PCT in 1980 , but this rose to around around $25 \%$ by the late 1990 s. Because the bulk of the patents in the sample were applied for between 1982 and 1987 the PCT application plays only a minor role as a way of seeking

\footnotetext{
${ }^{34}$ For all variables in table 1 a test of equal means was conducted. Numbers with * indicate significant differences at the $1 \%$ level.

${ }^{35}$ I am grateful to Stefan Wagner from Inno-tec Munich who provided excellent citation information from the EPOLINE data bases, collected in cooperation with the EPO.
} 
patent protection. Across the entire sample, protection was sought via PCT application in $4.7 \%$ of the cases and via EPO application in 26.6\%. Within the litigated group of patents, the share of PCT_APPL is significantly lower $(3.2 \%)$. The numbers for original EPO patents (EPO_APPL) differs not significantly between the two groups.

A dummy variable indicates if an opposition procedure had been filed (Opposition) either at the EPO or at the DPMA. I have not differentiated between the procedures at the German Patent Office and the EPO, even though national opposition affects the validity of a patent only for the German market, a European one has effects for all designated states. For a domestic litigation suit only the issue of prior opposition as such is important. ${ }^{36}$ Litigated patents were opposed five times more often than patents in the control group. This ratio is most striking in order of magnitude.

\section{Characterisitcs of the patentee}

The dummy variable INDIVIDUAL defines whether the patentee is an individual or a corporation. In cases where the patentee as potential plaintiff was indicated as corporation, size and industry variables were added. For the foreign corporations the data were completed by searches using internet and information from several firm databases. ${ }^{37}$ Finally four size classes were constructed using sales figures. The first includes all individuals, the second small firms with sales totaling less than 10 million DM (SMALL_FIRM); the third is for medium sized firms with sales of more than 10 million DM up to 100 million DM (MEDIUM_SIZE_FIRM); the fourth class includes all large firms with sales of more than 100 million DM (LARGE_FIRM). ${ }^{38}$ While the share of SMALL_FIRM for litigated patents is $26.1 \%$, 2.7 times higher than the $9.6 \%$ in the group of unlitigated patents, this difference decreases for MEDIUM_SIZE_FIRM from $33.4 \%$ to $26.8 \%$, by factor 1.2 ). LARGE_FIRM are less frequently represented as patentees in the group of litigated patents than in the unlitigated group $(31.3 \%$ versus $39.5 \%)$. The relation is 0.8 . Individuals are less likely to be owners of a litigated patent. $24.2 \%$ of the unlitigated patents are held by individuals compared to only $9.1 \%$ of the litigated patents. Table 1 shows that all of differences are statistically significant.

I constructed the variable patent portfolio size (PATENT_PORTFOLIO) as the number of all patents of the patentee which were in force at the time the law suit was filed. It is the sum of all applications granted at the DPMA starting from 1978 to the year of filing. I also used the EPO applications which were designated for Germany because I intended to interpret the portfolio partly as a means of bargaining in the German market. The average portfolio size is 1,590. It ranges from 1 to 66,369. As expected, for foreign firms the portfolio size is smaller with 1,262 on average. Even though the difference between domestic and foreign applicants is great, it is not statistically significant. Among the litigating parties foreigners have a larger portfolio than those for Germany.

Additionally, I used the respective owner's base nation to identify domestic and foreign patentees. The owners are from the EU, the U.S., Japan, and others (OWNER_FOR_EU, OWNER_FOR_US, OWNER_FOR_JP, and OWNER_FOR_OTHER). The probability of litigation should be higher for Germans, of course, and also among the foreigners with respect to European patentees because of the lower expected costs. The share of patent owners who have their headquarters in Germany is almost two-thirds in the sample. Within the group of litigating parties it increases up to 76.6\%. Among the foreign patent holders the share of European patentees is more than 50 percent. As expected, patentees from the EU are more likely to be involved in litigation suits than patentees from other foreign countries. U.S. patentees are represented less often in the group of litigating parties and the shares of Japanese and other owners are even lower.

\footnotetext{
${ }^{36}$ Between European and German patents no significant differences in opposition frequency is observable. The shares of opposed patents are 16.4 and 15.7 , respectively.

${ }^{37}$ Commercially provided firm databases are Creditreform, MARKUS, AMADEUS, Hoppenstedt, and for the U.S., the COMPUSTAT file.

${ }^{38}$ The size classes defined in Euro are approximately: less than 5 mio. Euro, up to 50 mio. Euro, more than 50 mio. Euro.
} 


\section{$5 \quad$ Empirical results}

\subsection{Descriptive statistics}

For the analysis of the determinants of patent litigation suits in Germany I used a sample of 824 patents that were applied and granted at the German Patent Office or the European Patent Office and which were involved in patent litigation at the district court in Düsseldorf or Mannheim during the period 1993 to $1995 .{ }^{39}$ Applications for preliminary injunctions are included within the group of litigated patents. They are regarded as filed suits as well. The number of applications for a preliminary injunction almost doubled from 69 in the preiod 1972-1974 to 109 in the period from $1993-1995 .{ }^{40}$ First, I want to describe the structure of the litigation sample as it compares to the control group and to general characteristics of the population of all German patents.

As Lanjouw und Schankerman found for the U.S. the litigation rate varies dramatically among technologies. IPC-codes are used at the DPMA and EPO in the same way to assign inventions to a field of technology. Each patent will be assigned to one (principle) or more IPC classes, each of which consists of a 4 digit main class and a 4-5 digit subclass. The principle IPC class is used to categorize the patent into a technological area (drugs, chemical, mechanical, electronics, others). To be able to compare the results with the U.S. studies the data were aggregated similar to the area-definition used by Lanjouw und Schankerman (1997). Table 4 shows how the distribution within the main technological area differs among the population of all patents within the same cohorts as the sample. It is to be seen that the share of pharmaceutical patents is roughly the same in the sample as in compared to the universe. However, patents applied for in chemicals represent half of the share within the sample distribution compared to the overall patent grants. Imitation of chemical raw material is relatively easy to detect. This should be true for pharmaceutical patents as well. However, because biotechnology is included here, which was a relatively new technology in the period of investigation, the share of pharmaceutical patents involved in disputes is higher than the overall share would suggest. Mechanical patented inventions are the subject of litigation disputes more often than their share among the universe indicates.

Table 4 shows the differences in the technology structures. The most striking fact is that the share of litigated patents granted in Mechanics amounts to $52.18 \%$ while it is only $37.79 \%$ on average in the German population in comparable application years. It is more complicated to define precisely claims of a mechanical invention than, for instance, a chemical formula. Thus, infringement is more likely and, more importantly, the proof of infringement is more difficult to obtain. Parties will have different expectations of their probability of winning, making settlement less likely. Only $8.13 \%$ of the litigated patents are assigned to Chemicals while this share in the German population is more than twice as high. Imitation of chemical raw materials is relatively easy to detect and makes outcomes of litigation suits easy to predict which, in turn, makes settlement more profitable. Again, this should also hold true for pharmaceutical patents. However, pharmaceuticals are more likely to be involved in litigation suits than chemical patents. Because this field includes biotechnology, which was a relatively new technology in the period of investigation, the share of pharmaceutical patents involved in disputes $(8.01 \%)$ is higher than the overall share $(5.83 \%)$ would suggest. Lanjouw und Schankerman (2003) report greater shares in Drugs and Other Health, in Chemical and Electronics within in the sample of all filed cases in the U.S. for the suit filing cohorts between 1978 and 1995 in comparison to Germany. Only Mechanical patents have a higher share in Germany within the sample of litigated patents. The reason lies partly in the differences in patenting behavior between the two countries. Germany traditionally has a higher percentage of the more traditional mechanical patents owned by small and medium sized firms. The probability of litigation is c.p. higher when more patents are in force. Case study evidence from the chemical industry reports that large German chemical and pharmaceutical companies try to avoid patent litigation by offering credible settlement amounts and/or cross-licensing agreements.

\footnotetext{
${ }^{39}$ Stauder (1996) determined that these two district courts treat about 55 to $60 \%$ of all patent litigation cases in Germany. I assume in this paper that the affinity forfiling suits at certain district courts did not change decisively over time. Likewise, the reasons for forum shopping did not change from the analysis period of Stauder (1989) 1971 to 1973 to the recent period from 1993 to 1995.

${ }^{40}$ See for comparison the data in Stauder (1989).
} 
Table 5 contains the distribution across age classes. The average age of a litigated patent is 8.3 years. About one-third of litigated patents are less than 6 years old, and one-third is between 6 and 10 years old. There is no reliable information on the average age of a patent in the universe of all German patents in the period from 1993 to 1995. Therefore, these large shares of young litigated patents can be caused by a general tendency to infringe and subsequent provoke suits at an average age of 8.3 years. However, it may be that across all technology classes the average age of a patent in force is around this figure, and age has no impact on the probability to litigate.

As described in section 4.3 the construction of the control group results in a sample litigation rate of 0.5 . Table 6 shows how this litigation rate varies among the groups of ownership and for different citation figures. German owners are more likely to be involved in litigation than owners from abroad. Sample probability of litigation decreases as the geographical distance from Germany increases. Looking at the last column of table 6, "Total" points out that the German patent owners in the sample face a sample litigation rate of 0.58 , while that of all foreigners is below 0.50 . Patents with less than 4 forward citations have sample litigation rates lower than 0.5 . While Germans still face a sample probability of 0.48 patentees from outside the triad are only in 0.15 (Japan) and 0.11 of Disputes. This table confirms the fact that the litigation rate rises with the number of forward citations, which points to a higher probability of litigation for more valuable patents. For patents owned by Germans this effect is monotone in the number of citations while for EU owners and patentees from other countries it is not. Irrespective of the origin of the owner, in cases where the number of forward citations is higher than nine the sample probability of litigation is at least 15 percentage points greater than the constructed litigation probability. In table 7 I show the sample litigation rates for patentees of different absolute size owning patent portfolios of various sizes. In general large firms have a sample litigation probability which is less than the average, 0.44 . However, if the firm owns a large portfolio with more than 2,000 patents, this probability drops further to 0.20. Small firms have an high expected probability of litigation. For firms with a small patent portfolio of ten patents at most, the sample probability of litigation amounts to 0.80. Surprisingly, medium-sized firms with a large portfolio have a very high observed probability of litigation (0.70), while firms with a smaller patent portfolio do not significantly deviate from 50 percent. This number is mainly determined by multiple cases of one company defending various patents.

\subsection{Results from probit estimation}

In this section I present the results of the probit analysis. I suppose that the probability of litigation, given that patent infringement has taken place and has been detected, is correlated to the value of the involved intellectual property right (first block of Table 8) a number of characteristics of the owner of the right, and market characteristics (second block of Table 8). FORW_CIT_D+E is positive and highly significant. It displays that an increasing number of forward citations leads to a higher sample probability of litigation at a decreasing rate indicated by a negative parameter of FORW_CIT_D+E_SQU. This result confirms H1 and is in line with the result of Lanjouw und Schankerman (2003), related studies by Graham und Somaya (2004) for software patents and Harhoff und Reitzig (2004) for determinants of opposition against pharmaceuticals. Adding one additional citation would raise the litigation probability by 4.5 percentage points. ${ }^{41}$

BACKW_CIT_D+E has a positive impact on the likelihood of litigation processes in Germany. This effect is estimated precisely and turns out to be robust against sample variation. One additional backward citation added to the mean would increase the probability of litigation by 4.7 percent points. This effect is in the same dimension as that observed for forward citations and is highly significant. The impact of backward citations on the likelihood of patent litigation diminishes as the number of backward citations increases, a fact illustrated by a negative parameter for BACKW_CIT_D+E_SQU. The result suggests that a high number of backward citations indicate either that the patent is likely questionable because of its similarity to a greater number of previous granted patents or that the value of the patent raises, as I argued

\footnotetext{
${ }^{41}$ I used citations per claim in a different probit specification. Doing so I assigned more attention to the valuation of a certain inventive step documented in one claim. The results remained qualitatively the same and were in the magnitude of those of Lanjouw und Schankerman (2003). But the estimation was not as precise than the one preferred in this paper and is not reported here.
} 
in 3.2. According to H2 I found evidence that this effect dominates the impact of lowered uncertainty in the distinct field of technology. Lanjouw und Schankerman (2003) found a negative effect of backward citations on the probability of litigation of patents in the U.S. Harhoff und Reitzig (2004) described no significant effect of the total number of backward citations on the likelihood of opposition at the European Patent Office for pharmaceuticals but point out that the composition matters considerably. ${ }^{42}$ The more claims a patentee has declared the higher the probability of being litigated seems. One claim added to the mean of CLAIM raises this probability by 0.6 percentage points. This result confirms H4. It is a small but precisely estimated parameter and is again in line with the similar estimation of Lanjouw und Schankerman (2003).

Moreover, patents with a large family size prove to be more likely to be involved in infringement suits. The effect of FAMILY_SIZE on the probability of litigation is positive and highly significant. One additional designated state as new family member would raise the probability of litigation by 0.8 percentage points for the sample. These results do not allow the rejection of H3. Regarding the impact of family size on the likelihood of opposition, Harhoff und Reitzig (2004) found a nonlinear effect which is not apparent in this infringement analysis. As I mentioned before the value correlates are all positively correlated with the probability of litigation and are in the line with previous research.

Within the second block the parameters of the patentee's characteristics are displayed. The probability of an infringement suit falls as the PATENT_PORTFOLIO increases as I expected in H8. I also prove that the effect increses with a growing number of patents in the portfolio. This is consistent with the results of Lanjouw und Schankerman (2003) and the argument that experience in holding and enforcing patent rights has a positive effect on the ability to settle. Additionally, as they argue, there are "beneficial" enforcement spillovers "among patents within a given firm." The ability to settle is much greater for larger firms with larger patent portfolios. Adding 100 patents to the mean portfolio size of 1,590 decreases the sample litigation rate by 2.3 percentage points. Table 9 displays a different specification showing the effects of patent portfolio size in 5 classes. It is clearly to be seen that the probability of litigation falls with the number of patents in the portfolio at an increasing rate. This effect is significant for German patent owner.

In order to test H9 the variables INDIVIDUAL, SMALL_FIRM, MEDIUM_SIZE_FIRM, and LARGE_FIRM are used to indicate the absolute size of the patentee as a determinant of patent litigation. Using INDIVIDUAL as its base category, Table 8 and table 9 show that regardless of their size companies have a significantly higher probability of patent litigation than individual patentees. This result is statistically significant. It provides no support for H9. One explanation could be that individuals have, in fact, high stakes in patent litigation relative to their own wealth. However, in relation to potential infringers and defendants which are likely to be large firms, the stakes are smaller. Thus, potential defendants might both be large and have a lower probability to be involved in litigation due to their accepting reasonable settlement offers. However, it does not explain the contrast to the findings for the U.S. Firstly, differences in the litigation system between Germany and the U.S. may create different incentives, especially for individuals. Due to cost rewarding rules and damage calculation individuals in Germany might be better off with relatively lower settlement amounts compared to U.S. individual patentees which leads to less litigation. Secondly, individuals on the German market might be more pessimistic because of the financial burden a litigation case creates and because of the imperfect financial market, which leads to more settlement and less litigation by individuals involved in those suits. Companies face with growing company size a smaller probability of litigation. In other words, the litigation is, c.p. in fact most likely for small firms with turnover less than 10 million DM compared to other patentees. This result confirms $\mathrm{H} 7$ and is in the line with the results of the studies named above. There is no monotonic relationship and the marginal effect for MEDIUM_SIZE_FIRM is lower than for large firms. One explanation might be, that for large firms it may be of strategically advantageous not to settle sometimes in order to signal a tough enforcement strategy against infringers. After a reputation as an aggressive plaintiff has been established more profitable settlement agreements can be achieved in subsequent disputes.

\footnotetext{
${ }^{42}$ Harhoff und Reitzig (2004) found a significant positive effect of X documents. Because the information on the shares of $\mathrm{X}$ and $\mathrm{A}$ is not available for German references, only the pure number of citations was used here. A detailed investigation as Harhoff und Reitzig (2004) did using X, Y and A citations would reveal more about the questioning or strengthening properties of backward citations. This is especially important for German applications where such distinctions are not documented, yet.
} 
A set of ownership variables in table 8 shows that foreign patent owners as a whole have a lower propensity to file suit, though foreign owners from the European Union are more likely to sue than U.S. or Japanese patentees. The parameters of OWNER_FOR_EU, OWNER_FOR_US, OWNER_FOR_JP, and OWNER_FOR_OTHER are significant and growing raising with the geographical distance. This is in line with the more general results of Lanjouw und Schankerman (2003) and confirms my expectations in section 3.2. The effects are large and robust and show that foreign patentees may expect a lower probability of winning because of their disadvantage in evaluating the information. This leads to a lower propensity to litigate (Priest und Klein 1984). I do not find support for an effect of the path of seeking patent protection neither for PCT_APPL nor for EPO_APPL. Hypotheses H5 has to be rejected. As I define EPO_APPL as originally filed EPO-application I found no significant difference between patents originally filed as EPO or German patents concerning likelihood of patent litigation. Since both application paths leads to the a German intellectual property rights, there is no jurisdictional difference. All possible value diversity is captured by the value correlates. Regarding the average date of patent application in the sample (198386) this route of seeking patent protection might not play an important role to influence the litigation probability. Though this indicator is proven to be correlated with the value of patents.

Now I turn to columns 3 and 4 of table 8. Patents that have survived an opposition procedure have a higher probability of litigation. The specification in columns 3 and 4 reveals that the expected probability of litigation for a patent in the sample increases by 35.9 percentage points when an opposition has been filed, compared to patents with the same characteristics that did not face an opposition. Thi proves that H6 can not be rejected. The effect is considerable and estimated precisely. Besides the parameters of FORW_CIT_D+E and Backw_CIT_D+E decrease the results are fairly robust against this change. This result elucidates opposition as an indicator of patent value and may partly explain some of the residual patent value (Harhoff et al. 2003). After withstanding opposition the patentee's position will be very strong. The patentee can be fairly confident and can expect a high probability of winning at trial which leads to more litigation (Priest und Klein 1984). The high magnitude of the coefficient suggests that this variable not only reflects the higher value of the patent, but, also gives the speciality of the procedure a higher weight. An explanation might be that an opponent signals that the patent will be subject of future infringement and subsequent disputes. If the patent is questionable from the beginning of its granted life and is not revoked after an opposition, an infringing action and a subsequent infringement suit are more likely for it than for patents that have not been under question through an opposition procedure. The results of the analysis do not suggest that patents that have successfully withstood challenges are less likely to produce costs and uncertainty during litigation suits (Graham et al. 2003).

\section{Conclusion}

In this paper I have presented an empirical analysis of the determinants of patent litigation suits in Germany. It is the first study of its kind undertaken for Germany. The information about the suits, the involved patents, and the parties was obtained by searching the written records at the district courts of Mannheim and Düsseldorf between 1993 and 1995. Additionally, searching the patent data bases of the German and European Patent Offices and in a number of corporate databases completed the data set.

The multivariate probit analysis confirms that highly valuable patents are more often the subject of infringement suits. It is not possible to observe whether those patents have been infringed more frequently or whether they are more frequently litigated before court. Using variables which were tested in prior work as highly correlated with the value of the patent right turned out to have a positive impact on the probability of litigation. In this way the results confirm those of Lanjouw und Schankerman (2003). However, value correlates such as many forward citations, large family sizes and a high number of claims point to a higher risk of being involved in an infringement suit. Suits are less likely if the parties are able to settle on justifiable costs. Patent owners with a large portfolio of previous patents may have experience in defending patents and giving them a protecting belt of patents around the potentially infringed one. Additionally, they can use the large portfolio as bargaining chips in licensing negotiations. The differences regarding backward citations are possibly due to their different composition. At this point further research must be conducted to investigate the impact of the characteristics inherent to the U.S. 
and German patent and litigation systems so that the results can be compared. I further conclude, that an opposition prior to a suit is a signal of potential further potential infringement and subsequent disputes. I would not expect that an opposition with possibly amending results for the patent claims will reduce the propensity to litigate.

Characteristics of the patentee, such as his or her ability to interact repeatedly and his experience in exploiting and enforcing patents, measured by patent portfolio size lead to significantly lower probabilities of litigation. A credible threat to file a suit, measured in absolute size (sales or employees) of the plaintiff, has a negative impact on the filing rate within the sample. Evidence was also found that small firms tend to have a higher risk of getting involved into a suit. At this point it is not clear whether this is due to the relatively high profits these firms expect from their invention or if there is some kind of self serving bias (Babcock und Loewenstein 1997). This bias would lead these firms to form their expectations towards higher rates of winning at trial and higher gains from suits. However the costs of those suits will harm the small firms more seriously and may probably lead to financial distress. Additionally, the uncertainty during the course of the case will cause further losses. This will have a decisive impact on insurance rates regarding litigation risks. A detailed analysis of the course of the cases will lead to more insight. It is somewhat satisfying that in contrast to the empirical findings for the U.S., the propensity of individuals to be involved in patent litigation is relatively low compared to companies due to less experience, high monitoring efforts, and typically weaker financial background. This this is evident in equal measure for both domestic and foreign individual patentees. 


\section{Literatur}

Astebro, T. (2003). The Return to Independent Invention: Evidence of Unrealistic Optimism, Risk Seeking or Skewness Loving?, Economic Journal 113, 226-239.

Babcock, L. und Loewenstein, G. (1997). Explaining Bargaining Impasse: The Role of Self-Serving Biases, Journal of Economic Perspectives 11(1), 109-126.

Bebchuk, L. A. (1984). Litigation and Settlement Under Imperfect Information, RAND Journal of Economics 15(3), 405-415.

Blackburn, R. (2000). Extraterritorial enforcement: Practical considerations for lawyers, CASRIP Publication Series: Rethinking International Intellectual Property 6, 63-67.

Cohen, W. M., Nelson, R. R. und Walsh, J. P. (2000). Protecting Their Intellectual Assets: Appropriability Conditions and Why U.S. Manufacturing Firms Patent (or not), Working Paper No. 7552, National Bureau of Economic Research (NBER), Cambridge, MA.

Cooter, R. und Rubinfeld, D. L. (1989). Economic Analysis of Legal Disputes and Their Resolution, Journal of Economic Literature 27, 1067-1097.

Crampes, C. und Langinier, C. (2002). Litigation and Settlement in Patent Infringement cases, RAND Journal of Economics 33(2), 258-274.

Graham, S. J. H., Hall, B. H., Harhoff, D. und Mowery, C. (2003). Patent Quality Control: A Comparison of U.S. Patent Reexaminations and European Patent Opposition, in: W. M. Cohen und A. Merrill (eds), Intellectual Property in the Knowledge-based Economy, The National Academic Press, Washington, D.C.

Graham, S. und Somaya, D. (2004). Complementary Uses of Patents, Copyrights and Trademarks by Software Firms: Evidence from Litigation, Working paper, Business School at Georgie Tech, Atlanta.

Hall, B. H. und Ziedonis, R. H. (2001). The Patent Paradox Revisited: An Empirical Study of Patenting in the U.S. Semiconductor Industry, 1979-1995, RAND Journal of Economics 32, 101-128.

Hall, B. H., Jaffe, A. B. und Trajtenberg, M. (2000). Market Value and Patent Citations: A First Look, Working Paper No. 7741, National Bureau of Economic Research (NBER), Cambridge, MA.

Hall, B. H., Jaffe, A. B. und Trajtenberg, M. (2002). The NBER Patent Citations Data File: Lessons, insights and Methodological Tools, in: A. B. Jaffe und M. Trajtenberg (eds), Patents, Citation, and Innovation. A Window on the Knowledge Economy, The MIT Press, Cambridge, MA.

Harhoff, D. und Reitzig, M. (2004). Determinants of Opposition against EPO Patent Grants - The Case of Biotechnology and Pharmaceuticals, Research Policy (forthcoming).

Harhoff, D., Scherer, F. M. und Vopel, K. (2003a). Citations, Family Size, Opposition and the Value of Patent Rights, Research Policy 32, 1343-1363.

Harhoff, D., Scherer, F. M. und Vopel, K. (2003b). Exploring the Tail of Patented Invention Value Distribution, in: O. Granstrand (ed.), International Patent Litigation, Kluwer Academic Publishers, Boston.

Katz, A. (1987). Measuring the Demand for Litigation: Is the English Rule Really Cheaper?, Journal of Law, Economics and Organization 3(2), 143-176.

Körner, E. (1984). Germany, Federal Republic of, in: M. Meller (ed.), International Patent Litigation, The Bureau of National Affairs, Inc., Washington, D.C.

Lanjouw, J. O. und Lerner, J. (1998). The Enforcement of Intellectual Property Rights: A Survey of the Empirical Literature, Annales d'Economie et de Statistique 49/50, 223-246. 
Lanjouw, J. O. und Lerner, J. (2001). Tilting the Table? The Use of Preliminary Injunctions, Journal of Law and Economics XLIV, 573-603.

Lanjouw, J. O. und Schankerman, M. (1997). Stylized Facts of Patent Litigation: Value, Scope and Ownership, Working Paper No. 6297, National Bureau of Economic Research (NBER), Cambridge, MA.

Lanjouw, J. O. und Schankerman, M. (2001). Characteristics of Patent Litigation: A Window on Competition, RAND Journal of Economics 32, 129-151.

Lanjouw, J. O. und Schankerman, M. (2003). Enforcement of Patent Rights in the United States, in: W. M. Cohen und A. Merrill (eds), Patents in the Knowledge-Based Economy, The National Academic Press, Washington, D.C.

Marshall, H. (2000). The enforcement of Patent Rights in Germany, International Review of Industrial Property and Copyright Law 31(6), 646-676.

Meurer, M. J. (1989). The Settlement of Patent Litigation, RAND Journal of Economics 20(1), 77-91.

Michel, J. und Bettels, B. (2001). Patent Citation Analysis: A closer Look at the basic Input Data from Patent Search Reports, Scientometrics 51(1), 185-201.

Ordover, J. A. und Rubinstein, A. (1986). A Sequential Concession Game with Asymmetric Information, Quarterly Journal of Economics 101(4), 879-888.

P'ng, I. P. L. (1983). Strategic Behavior in Suit, Settlement and Trial, Bell Journal of Economics $14(2), 539-550$.

Perloff, J. und Rubinfeld, D. (1987). Settlements in private Antitrust Litigation, in: L. White (ed.), Private Antitrust Litigation, MIT Press.

Pitz, J. (1999). Economic Aspects of Patent Litigation in Europe, Patent World .

Priest, G. L. und Klein, B. (1984). The Selection of Disputes for Litigation, Journal of Legal Studies XIII, 1-55.

Putnam, J. (1996). The Value of International Patent Rights, PhD thesis, Yale University, New Haven.

Reitzig, M., Henkel, J. und Heath, C. (2003). Who really Profits from Patent Infringements? A Comparative International, Technical report, University of Munich.

Somaya, D. (2003). Strategic Determinants of Decisions not to Settle Patent Litigation, Strategic Management Journal 24, 17-38.

Spier, K. E. (1994). Pretrial Bargaining and the Design of Fee-shifting Rules, RAND Journal of Economics 25(2), 197-214.

Stauder, D. (1989). Patent- und Gebrauchsmusterverletzungsverfahren in der Bundesrepublik Deutschland, Großbritannien, Frankreich und Italien. Eine rechtstatsächliche Untersuchung, Schriftenreihe zum gewerblichen Rechtsschutz, Carl Heymanns Verlag, Köln.

Stauder, D. (1996). Aspekte der Durchsetzung gewerblicher Schutzrechte: Fachkundiger Richter, schnelles Verfahren und europaweites Verletzungsverbot, Aktuelle Herausforderungen des Geistigen Eigentums. Festschrift für F.-K. Beier.

Thumm, N. (2000). Intellectual Property Rights. National Systems and Harmonisation in Europe, Physica, Heidelberg.

Traijtenberg, M. (1990). A Penny for your Quotes. Patent Citations and the Value of Innovation, $R A N D$ Journal of Economics 21(1), 172-187. 
Waldfogel, J. (1998). Reconciling Asymmetric Information and Divergent Expectations Theories of Litigation, Journal of Law and Economics 41, 451-476.

Ziedonis, R. H. (2003). Patent Litigation in the U.S. Semiconductor Industry, in: W. M. Cohen und A. Merrill (eds), Patents in the Knowledge-Based Economy, The National Academic Press, Washington, D.C.

von Meibom, W. und Pitz, J. (1996). Patent Litigation in Germany, in: M. Pantuliano, D. Harris, A. Horton, Mollet-Vieville, W. von Meibom, J. Pitz, G. Dragotti und S. de Wit (eds), Multinational Patent Litigation, Financial Times Law \& Tax. 
Tabelle 1: Descriptive statistics of all exogenous variables

\begin{tabular}{|c|c|c|c|}
\hline & All & Litigated & Matched \\
\hline Exogenous Variable & $\begin{array}{c}\text { Mean } \\
(\mathrm{SD})\end{array}$ & $\begin{array}{c}\text { Mean } \\
(\mathrm{SD})\end{array}$ & $\begin{array}{c}\text { Mean } \\
(\mathrm{SD})\end{array}$ \\
\hline FORW_CIT_D+E & $\begin{array}{c}2.329 \\
(4.302)\end{array}$ & $\begin{array}{r}3.412^{*} \\
(5.378)\end{array}$ & $\begin{array}{l}1.246^{*} \\
(2.403)\end{array}$ \\
\hline BACKW_CIT_D+E & $\begin{array}{c}2.981 \\
(2.733)\end{array}$ & $\begin{array}{c}3.430^{*} \\
(2.905)\end{array}$ & $\begin{array}{r}2.533^{*} \\
(2.470)\end{array}$ \\
\hline CLAIMS & $\begin{array}{c}9.558 \\
(8.394)\end{array}$ & $\begin{array}{c}10.500^{*} \\
(9.621)\end{array}$ & $\begin{array}{c}8.617^{*} \\
(6.831)\end{array}$ \\
\hline FAMILY_SIZE & $\begin{array}{c}5.137 \\
(5.647)\end{array}$ & $\begin{array}{c}5.576^{*} \\
(6.234)\end{array}$ & $\begin{array}{c}4.697^{*} \\
(4.956)\end{array}$ \\
\hline OPPOSITION & $\begin{array}{c}0.160 \\
(0.367)\end{array}$ & $\begin{array}{c}0.271^{*} \\
(0.445)\end{array}$ & $\begin{array}{c}0.050^{*} \\
(0.218)\end{array}$ \\
\hline EPO_APPL & $\begin{array}{c}0.266 \\
(0.442)\end{array}$ & $\begin{array}{c}0.260 \\
(0.439)\end{array}$ & $\begin{array}{c}0.272 \\
(0.445)\end{array}$ \\
\hline PCT_APPL & $\begin{array}{c}0.047 \\
(0.211)\end{array}$ & $\begin{array}{c}0.032^{*} \\
(0.175) \\
\end{array}$ & $\begin{array}{r}0.062^{*} \\
(0.241)\end{array}$ \\
\hline PATENT_PORTFOLIO & $\begin{array}{c}0.159 \\
(0.713)\end{array}$ & $\begin{array}{c}0.074^{*} \\
(0.428)\end{array}$ & $\begin{array}{c}0.244^{*} \\
(0.905)\end{array}$ \\
\hline INDIVIDUALS & $\begin{array}{c}0.166 \\
(0.372)\end{array}$ & $\begin{array}{c}0.091^{*} \\
(0.288)\end{array}$ & $\begin{array}{c}0.241^{*} \\
(0.428)\end{array}$ \\
\hline SMALL_FIRM & $\begin{array}{c}0.178 \\
(0.383)\end{array}$ & $\begin{array}{c}0.261^{*} \\
(0.439)\end{array}$ & $\begin{array}{c}0.096^{*} \\
(0.295)\end{array}$ \\
\hline MEDIUM_SIZE_FIRM & $\begin{array}{c}0.302 \\
(0.459)\end{array}$ & $\begin{array}{c}0.335^{*} \\
(0.472)\end{array}$ & $\begin{array}{c}0.268^{*} \\
(0.443)\end{array}$ \\
\hline LARGE_FIRM & $\begin{array}{c}0.354 \\
(0.478)\end{array}$ & $\begin{array}{c}0.313^{*} \\
(0.464)\end{array}$ & $\begin{array}{c}0.394^{*} \\
(0.489)\end{array}$ \\
\hline OWNER_DE & $\begin{array}{c}0.667 \\
(0.471)\end{array}$ & $\begin{array}{c}0.771^{*} \\
(0.421)\end{array}$ & $\begin{array}{c}0.564^{*} \\
(0.496)\end{array}$ \\
\hline OWNER_FOR_EU & $\begin{array}{c}0.174 \\
(0.379)\end{array}$ & $\begin{array}{c}0.146^{*} \\
(0.353)\end{array}$ & $\begin{array}{c}0.203^{*} \\
(0.402)\end{array}$ \\
\hline OWNER_FOR_US & $\begin{array}{c}0.096 \\
(0.295)\end{array}$ & $\begin{array}{c}0.065^{*} \\
(0.248)\end{array}$ & $\begin{array}{c}0.127^{*} \\
(0.334)\end{array}$ \\
\hline OWNER_FOR_JP & $\begin{array}{c}0.047 \\
(0.211)\end{array}$ & $\begin{array}{c}0.015^{*} \\
(0.120)\end{array}$ & $\begin{array}{c}0.079^{*} \\
(0.270)\end{array}$ \\
\hline OWNER_FOR_Other & $\begin{array}{c}0.015 \\
(0.122)\end{array}$ & $\begin{array}{c}0.004^{*} \\
(0.060)\end{array}$ & $\begin{array}{r}0.027^{*} \\
(0.161)\end{array}$ \\
\hline Number of observation & 1648 & 824 & 824 \\
\hline
\end{tabular}

Numbers with ${ }^{*}$ differ statistically significant at $1 \%$ level. 
Tabelle 2: Citation in EPO and DPMA by Litigated and Non-Litigated patents

\begin{tabular}{lcccccc}
\hline \hline & \multicolumn{2}{c}{ Litigated } & \multicolumn{2}{c}{ Non-Litigated } & \multicolumn{2}{c}{ All } \\
& Mean & Obs & Mean & Obs & Sample Mean & Obs \\
& $(\mathrm{SD})$ & & $(\mathrm{SD})$ & & $(\mathrm{SD})$ & \\
& 3.271 & 610 & 1.055 & 600 & 2.172 & 1210 \\
& $(2.252)$ & & $(0.087)$ & & $(0.126)$ & \\
FORW_CIT_D & 2.766 & 214 & 1.027 & 224 & 1.877 & 438 \\
& $(0.246)$ & & $(0.110)$ & & $(0.139)$ & \\
FORW_CIT_E & 3.412 & 824 & 1.246 & 824 & 2.329 & 1648 \\
& $(0.187)$ & & $(0.084)$ & & $(4.302)$ & \\
\hline \hline
\end{tabular}

Forward Citation are available for both offices. Forw_Cit_D+E is the sum of both after removing double counts.

Tabelle 3: Citation in EPO and DPMA by Litigated and Non-Litigated patents

\begin{tabular}{lcccccc}
\hline \hline & \multicolumn{2}{c}{ Litigated } & \multicolumn{2}{c}{ Non-Litigated } & \multicolumn{2}{c}{ All } \\
& Mean & Obs & Mean & Obs & Sample Mean & Obs \\
& $(\mathrm{SD})$ & & $(\mathrm{SD})$ & & $(\mathrm{SD})$ & \\
\hline BACKW_CIT_D & 2.964 & 610 & 1.828 & 600 & 2.401 & 1210 \\
& $(2.744)$ & & $(1.974)$ & & $(2.459)$ & \\
BACKW_CIT_E & 4.757 & 214 & 4.420 & 224 & 4.584 & 438 \\
& $(2.950)$ & & $(2.672)$ & & $(2.813)$ & \\
BACKW_CIT_D+E & 3.430 & 824 & 2.533 & 824 & 2.981 & 1648 \\
& $(0.101)$ & & $(0.086)$ & & $(2.733)$ & \\
\hline \hline
\end{tabular}

Backward Citation were available only for the original filing patent office. Backw_Cit_D+E is the combination of either Backw_Cit_DPMA or Backw_Cit_EPO. 
Tabelle 4: Distribution of Patents among Technological Areas, by litigated and unlitigated patents

\begin{tabular}{|c|c|c|c|c|}
\hline \multicolumn{5}{|c|}{ Frequency and Shares of Patents in Main Technological Areas } \\
\hline Area of technology & \multicolumn{2}{|c|}{ German population } & \multicolumn{2}{|c|}{ Sample of Litigated Patents } \\
\hline Pharmaceutical & 112,396 & $5.83 \%$ & 66 & $8.01 \%$ \\
\hline Chemical & 330,999 & $17.18 \%$ & 67 & $8.13 \%$ \\
\hline Electronic & 549,965 & $28.54 \%$ & 123 & $14.93 \%$ \\
\hline Mechanical & 708,983 & $36.79 \%$ & 430 & $52.18 \%$ \\
\hline Other & 224,598 & $11.66 \%$ & 138 & $16.75 \%$ \\
\hline Total & $1,926,941$ & $100.00 \%$ & 824 & $100.00 \%$ \\
\hline
\end{tabular}

Note: Patents for German population reported in PATDPA with application date from 1978 to 1993

Tabelle 5: Age of Patents at Time of Filing in the Sample of Litigated Patents

\begin{tabular}{ccc}
\hline \hline Patent's Age & & \\
(years from application date) & Number of patents & percent \\
\hline 0 to 5 & 255 & $30.95 \%$ \\
6 to 10 & 300 & $36.41 \%$ \\
11 to 15 & 216 & $26.21 \%$ \\
16 to 20 & 53 & $6.43 \%$ \\
\hline no. of firms & 824 & $100.00 \%$ \\
\hline
\end{tabular}

Note: The average age at the time of filing is 8.3 years 
Tabelle 6: Sample Probability of Litigation by Ownership and Forward Citations

\begin{tabular}{lccccccc}
\hline \hline \multicolumn{7}{c}{ Forward Citation } \\
\hline Owner from & 0 & $1-3$ & $4-7$ & $7-9$ & more than 9 & Total & Obs \\
\hline Germany & 0.48 & 0.57 & 0.74 & 0.78 & 0.88 & 0.58 & 1100 \\
EU & $(0.50)$ & $(0.50)$ & $(0.44)$ & $(0.42)$ & $(0.33)$ & $(0.49)$ & \\
& 0.21 & 0.59 & 0.78 & 1.00 & 0.71 & 0.42 & 287 \\
US & $(0.41)$ & $(0.50)$ & $(0.42)$ & $(0.00)$ & $(0.49)$ & $(0.49)$ & \\
& 0.27 & 0.26 & 0.65 & 1.00 & 0.78 & 0.34 & 159 \\
Japan & $(0.45)$ & $(0.44)$ & $(0.49)$ & $(0.00)$ & $(0.44)$ & $(0.48)$ & \\
& 0.15 & 0.11 & 0.17 & & 0.67 & 0.16 & 77 \\
other & $0.36)$ & $(0.32)$ & $(0.41)$ & & $(0.58)$ & $(0.37)$ & \\
& 0.11 & 0.00 & 1.00 & & & 0.12 & 25 \\
Total & $0.32)$ & $(0.00)$ & $(0.00)$ & & & $(0.33)$ & \\
& 0.38 & 0.52 & 0.72 & 0.80 & 0.85 & $(0.50)$ & 1648 \\
Obs & $(0.49)$ & $(0.50)$ & $(0.45)$ & $(0.40)$ & $(0.36)$ & $(0.50)$ & \\
\hline \hline
\end{tabular}

Table shows the sample probability of litigation depending on the origin of the patent owner and the number of forward citations. When sample probability of litigation is equal $1(0)$ there are only observations in either the group of litigated (unlitigated) patents. Standard errors in parentheses.

Tabelle 7: Sample Probability of Litigation by Portfolio Size and Firm Size of the patentee

\begin{tabular}{|c|c|c|c|c|c|c|}
\hline \multicolumn{7}{|c|}{ Size Classes of Patentees } \\
\hline Patent Portfolio & Individual & Small Firm & Medium-Sized Firm & Large Frim & Total & Obs \\
\hline 0 to 10 & $\begin{array}{c}0.32 \\
(0.47)\end{array}$ & $\begin{array}{c}0.80 \\
(0.40)\end{array}$ & $\begin{array}{c}0.56 \\
(0.50)\end{array}$ & $\begin{array}{c}0.52 \\
(0.50)\end{array}$ & $\begin{array}{c}0.53 \\
(0.50)\end{array}$ & 634 \\
\hline 11 to 250 & $\begin{array}{c}0.12 \\
(0.32)\end{array}$ & $\begin{array}{c}0.70 \\
(0.46)\end{array}$ & $\begin{array}{c}0.54 \\
(0.50)\end{array}$ & $\begin{array}{c}0.53 \\
(0.50)\end{array}$ & $\begin{array}{c}0.53 \\
(0.50)\end{array}$ & 633 \\
\hline 251 to 1000 & $\begin{array}{c}0.00 \\
(0.00)\end{array}$ & $\begin{array}{c}0.33 \\
(0.52)\end{array}$ & $\begin{array}{c}0.59 \\
(0.50)\end{array}$ & $\begin{array}{c}0.51 \\
(0.50)\end{array}$ & $\begin{array}{c}0.51 \\
(0.50)\end{array}$ & 152 \\
\hline 1001 to 2000 & & $\begin{array}{c}0.57 \\
(0.53)\end{array}$ & $\begin{array}{c}0.50 \\
(0.53)\end{array}$ & $\begin{array}{c}0.42 \\
(0.50)\end{array}$ & $\begin{array}{c}0.45 \\
(0.50)\end{array}$ & 65 \\
\hline more than 2000 & & $\begin{array}{c}0.43 \\
(0.53)\end{array}$ & $\begin{array}{c}0.70 \\
(0.47)\end{array}$ & $\begin{array}{c}0.20 \\
(0.40)\end{array}$ & $\begin{array}{c}0.29 \\
(0.46)\end{array}$ & 164 \\
\hline Total & $\begin{array}{c}0.27 \\
(0.45)\end{array}$ & $\begin{array}{c}0.73 \\
(0.44)\end{array}$ & $\begin{array}{c}0.55 \\
(0.50)\end{array}$ & $\begin{array}{c}0.44 \\
(0.50)\end{array}$ & $\begin{array}{c}0.50 \\
(0.50)\end{array}$ & 1648 \\
\hline $\mathrm{Obs}$ & 274 & 294 & 497 & 583 & 1648 & \\
\hline
\end{tabular}

Table shows the sample probability of litigation depending on the size of the patent owner and the number of patents in its portfolio. When sample probability of litigation is equal $1(0)$ there are only observations in either the group of litigated (unlitigated) patents. Standard errors in parentheses. 
Tabelle 8: Probit Estimation Specification: Probability of Patent Litigation

\begin{tabular}{|c|c|c|c|c|}
\hline & Parameter & Marginal Effect & Parameter & Marginal Effect \\
\hline & (1) & $(2)$ & (3) & (4) \\
\hline FORW_CIT_D & $\begin{array}{l}0.112^{* * *} \\
(0.015)\end{array}$ & $\begin{array}{l}0.045^{* * *} \\
(0.006)\end{array}$ & $\begin{array}{l}0.096^{* * *} \\
(0.015)\end{array}$ & $\begin{array}{l}0.038^{* * *} \\
(0.006)\end{array}$ \\
\hline FORW_CIT_D+E_SQU & $\begin{array}{l}-0.002^{* * *} \\
(0.000)\end{array}$ & & $\begin{array}{l}-0.001^{* * *} \\
(0.000)\end{array}$ & \\
\hline BACKW_CIT_D+E & $\begin{array}{l}0.118^{* * *} \\
(0.030)\end{array}$ & $\begin{array}{l}0.047^{* * *} \\
(0.012)\end{array}$ & $\begin{array}{l}0.106^{* * *} \\
(0.031)\end{array}$ & $\begin{array}{l}0.042^{* * *} \\
(0.012)\end{array}$ \\
\hline BACKW_CIT_SQU & $\begin{array}{c}-0.005^{* *} \\
(0.002)\end{array}$ & & $\begin{array}{l}-0.006^{* * *} \\
(0.002)\end{array}$ & \\
\hline CLAIMS & $\begin{array}{l}0.015^{* * *} \\
(0.004)\end{array}$ & $\begin{array}{l}0.006^{* * *} \\
(0.002)\end{array}$ & $\begin{array}{l}0.016^{* * *} \\
(0.005)\end{array}$ & $\begin{array}{l}0.006^{* * *} \\
(0.002)\end{array}$ \\
\hline FAMILY_SIZE & $\begin{array}{l}0.020^{* * *} \\
(0.007)\end{array}$ & $\begin{array}{l}0.008^{* * *} \\
(0.003)\end{array}$ & $\begin{array}{l}0.016^{* *} \\
(0.008)\end{array}$ & $\begin{array}{l}0.007^{* *} \\
(0.003)\end{array}$ \\
\hline PATENT_PORTFOLIO & $\begin{array}{l}-0.573^{* * *} \\
(0.157)\end{array}$ & $\begin{array}{l}-0.229^{* * *} \\
(0.062)\end{array}$ & $\begin{array}{l}-0.577^{* * *} \\
(0.159)\end{array}$ & $\begin{array}{l}-0.230^{* * *} \\
(0.063)\end{array}$ \\
\hline PATENT_PORTFOLIO_SQU & $\begin{array}{l}0.060^{* *} \\
(0.027)\end{array}$ & & $\begin{array}{l}0.064^{* *} \\
(0.027)\end{array}$ & \\
\hline SMALL_FIRM & $\begin{array}{l}1.134^{* * *} \\
(0.119)\end{array}$ & $\begin{array}{l}0.403^{* * *} \\
(0.034)\end{array}$ & $\begin{array}{l}1.092^{* * *} \\
(0.121)\end{array}$ & $\begin{array}{l}0.389^{* * *} \\
(0.035)\end{array}$ \\
\hline MEDIUM_SIZE_FIRM & $\begin{array}{l}0.682^{* * *} \\
(0.105)\end{array}$ & $\begin{array}{l}0.264^{* * *} \\
(0.039)\end{array}$ & $\begin{array}{l}0.616^{* * *} \\
(0.107)\end{array}$ & $\begin{array}{l}0.239^{* * *} \\
(0.040)\end{array}$ \\
\hline LARGE_FIRM & $\begin{array}{l}0.706^{* * *} \\
(0.110)\end{array}$ & $\begin{array}{l}0.274^{* * *} \\
(0.040)\end{array}$ & $\begin{array}{l}0.627^{* * *} \\
(0.112)\end{array}$ & $\begin{array}{l}0.244^{* * *} \\
(0.042) \\
\end{array}$ \\
\hline OWNER_FOR_EU & $\begin{array}{l}-0.354^{* * *} \\
(0.097)\end{array}$ & $\begin{array}{l}-0.140^{* * *} \\
(0.037)\end{array}$ & $\begin{array}{l}-0.379^{* * *} \\
(0.101)\end{array}$ & $\begin{array}{l}-0.150^{* * *} \\
(0.039)\end{array}$ \\
\hline OWNER_FOR_US & $\begin{array}{l}-0.742^{* * *} \\
(0.125)\end{array}$ & $\begin{array}{l}-0.278^{* * *} \\
(0.041)\end{array}$ & $\begin{array}{l}-0.757^{* * *} \\
(0.130)\end{array}$ & $\begin{array}{l}-0.284^{* * *} \\
(0.043)\end{array}$ \\
\hline OWNER_FOR_JP & $\begin{array}{l}-1.026^{* * *} \\
(0.196)\end{array}$ & $\begin{array}{l}-0.356^{* * *} \\
(0.050)\end{array}$ & $\begin{array}{l}-0.990^{* * *} \\
(0.197)\end{array}$ & $\begin{array}{l}-0.349^{* * *} \\
(0.053)\end{array}$ \\
\hline OWNER_FOR_Other & $\begin{array}{l}-1.029^{* * *} \\
(0.340)\end{array}$ & $\begin{array}{l}-0.352^{* * *} \\
(0.082)\end{array}$ & $\begin{array}{c}-0.919^{* * *} \\
(0.339)\end{array}$ & $\begin{array}{c}-0.326^{* * *} \\
(0.092)\end{array}$ \\
\hline EPO_APPL & $\begin{array}{c}-0.126 \\
(0.098)\end{array}$ & $\begin{array}{c}-0.050 \\
(0.039)\end{array}$ & $\begin{array}{c}-0.132 \\
(0.102)\end{array}$ & $\begin{array}{c}-0.053 \\
(0.040)\end{array}$ \\
\hline PCT_APPL & $\begin{array}{c}-0.108 \\
(0.176)\end{array}$ & $\begin{array}{c}-0.043 \\
(0.070)\end{array}$ & $\begin{array}{c}-0.120 \\
(0.183)\end{array}$ & $\begin{array}{c}-0.048 \\
(0.073)\end{array}$ \\
\hline OPPOSITION & & & $\begin{array}{l}0.995^{* * *} \\
(0.109)\end{array}$ & $\begin{array}{l}0.359^{* * *} \\
(0.032)\end{array}$ \\
\hline
\end{tabular}


Tabelle 8 - continued from previous page

Parameter Marginal Effect Parameter

Marginal Effect

(1)

(2)

(3)

(4)

\begin{tabular}{ccc}
\hline CONSTANT & $(1)$ & $(3)$ \\
& $(0.110)$ & $-1.091^{* * * * *}$ \\
\end{tabular}

Wald-statistic $\left(\chi^{2}\right.$ (degrees of freedom $\left.)\right)$

\begin{tabular}{lcc}
\hline Size variables & $81.86(3)^{* * *}$ & $92.77(3)^{* * *}$ \\
Ownership variables & $58.60(4)^{* * *}$ & $62.19(4)^{* * *}$ \\
Pseudo $\mathrm{R}^{2}$ & 0.18 & 0.22
\end{tabular}

Pseudo $\mathrm{R}^{2}$

1648

1648

Notes: Dependent Variable: Patent Litigation (0/1). The reference patent is owned by an Individual from Germany. Standard errors in parentheses. ${ }^{*},{ }^{* *},{ }^{* *}$ indicate that the parameter is significantly different from zero at the $10 \%, 5 \%, 1 \%$ significance level. 
Tabelle 9: Probit Estimation Specification: Probability of Patent Litigation using Patent Portfolio Classes

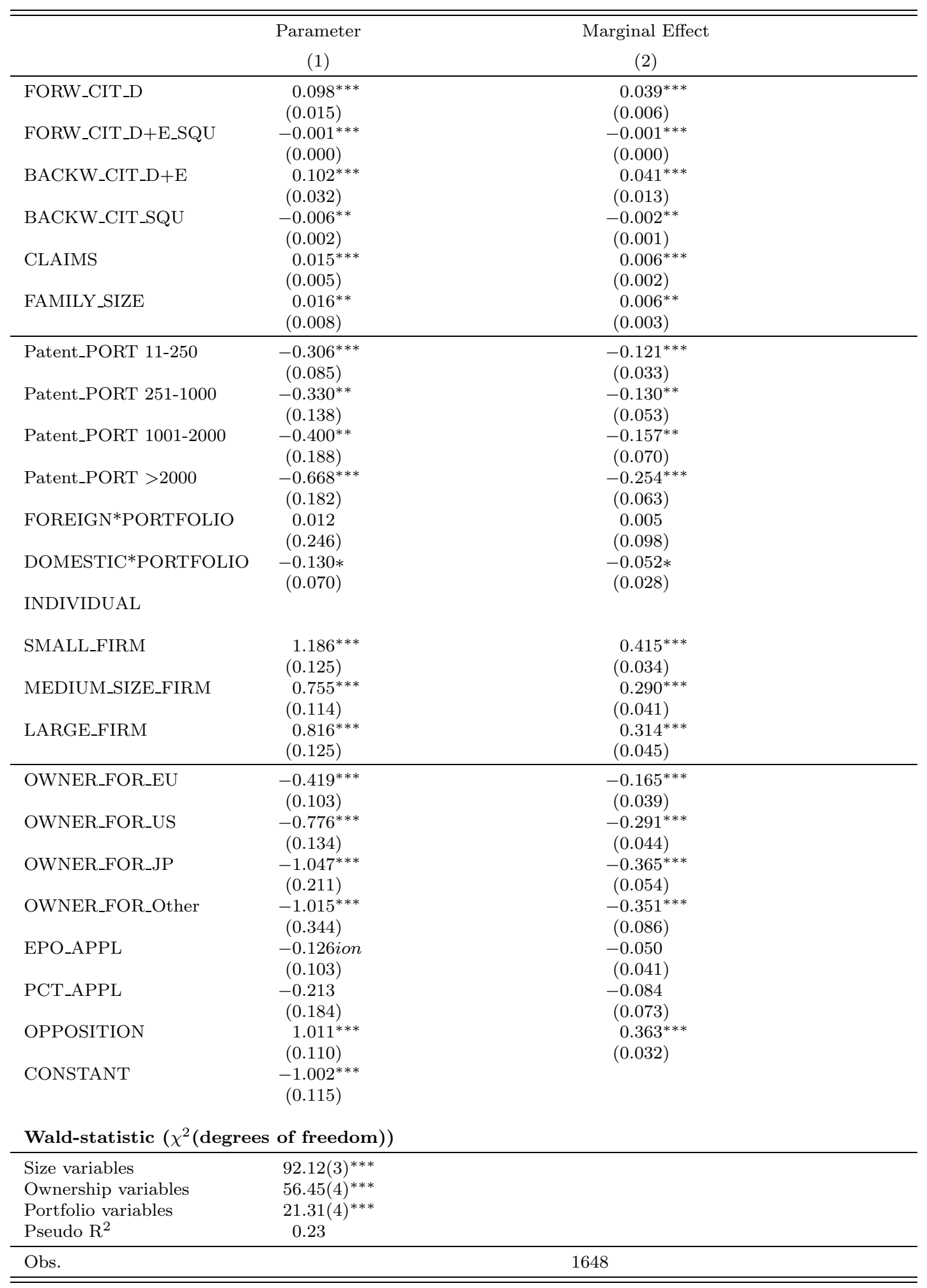

Notes: Dependent Variable: Patent Litigation (0/1). Portfolio_Size is used as categorical variable in size classes. The reference patent is owned by an Individual from Germany with a Patent Portfolio size less than 11. Standard errors in parentheses. ${ }^{*},{ }^{* *},{ }^{* * *}$ indicate that the parameter is significantly different from zero at the $10 \%, 5 \%, 1 \%$ significance level. 